Pure Appl. Chem., Vol. 85, No. 5, pp. 1047-1078, 2013.

http://dx.doi.org/10.1351/PAC-REP-13-03-02

(C) 2013 IUPAC, Publication date (Web): 29 April 2013

\title{
Atomic weights of the elements 2011 (IUPAC Technical Report)*
}

\author{
Michael E. Wieser ${ }^{1, \ddagger}$, Norman Holden², Tyler B. Coplen ${ }^{3}$, \\ John K. Böhlke ${ }^{3}$, Michael Berglund ${ }^{4}$, Willi A. Brand ${ }^{5}$, \\ Paul De Bièvre ${ }^{6}$, Manfred Gröning ${ }^{7}$, Robert D. Loss ${ }^{8}$, Juris Meija ${ }^{9}$, \\ Takafumi Hirata $^{10}$, Thomas Prohaska ${ }^{11}$, Ronny Schoenberg ${ }^{12}$, \\ Glenda O'Connor ${ }^{13}$, Thomas Walczyk ${ }^{14}$, Shige Yoneda ${ }^{15}$, and \\ Xiang-Kun Zhu ${ }^{16}$ \\ ${ }^{1}$ Department of Physics and Astronomy, University of Calgary, Calgary, Canada; \\ ${ }^{2}$ Brookhaven National Laboratory, Upton, NY, USA; ${ }^{3}$ U.S. Geological Survey, \\ Reston, VA, USA; ${ }^{4}$ Institute for Reference Materials and Measurements, Geel, \\ Belgium; ${ }^{5}$ Max Planck Institute for Biogeochemistry, Jena, Germany; ${ }^{6}$ Independent \\ Consultant on MiC, Belgium; ${ }^{7}$ International Atomic Energy Agency, Seibersdorf, \\ Austria; ${ }^{8}$ Department of Applied Physics, Curtin University of Technology, Perth, \\ Australia; ${ }^{9}$ National Research Council of Canada, Ottawa, Canada; \\ ${ }^{10}$ Kyoto University, Kyoto, Japan; ${ }^{11}$ Department of Chemistry, University of Natural \\ Resources and Applied Life Sciences, Vienna, Austria; ${ }^{12}$ Institute for Geosciences, \\ University of Tübingen, Tübingen, Germany; ${ }^{13} \mathrm{New}$ Brunswick Laboratory, Argonne, \\ IL, USA; ${ }^{14}$ Department of Chemistry (Science) and Department of Biochemistry \\ (Medicine), National University of Singapore (NUS), Singapore; \\ ${ }^{15}$ National Museum of Nature and Science, Tokyo, Japan; ${ }^{16}$ Chinese Academy of \\ Geological Sciences, Beijing, China
}

\begin{abstract}
The biennial review of atomic-weight determinations and other cognate data has resulted in changes for the standard atomic weights of five elements. The atomic weight of bromine has changed from 79.904(1) to the interval [79.901, 79.907], germanium from $72.63(1)$ to 72.630 (8), indium from 114.818(3) to 114.818(1), magnesium from 24.3050(6) to the interval [24.304, 24.307], and mercury from 200.59(2) to 200.592(3). For bromine and magnesium, assignment of intervals for the new standard atomic weights reflects the common occurrence of variations in the atomic weights of those elements in normal terrestrial materials.
\end{abstract}

Keywords: atomic-weight intervals; atomic-weight ranges; bromine; conventional atomicweight values; germanium; half-lives; indium; IUPAC Inorganic Chemistry Division; magnesium; mercury; standard atomic weights.

\footnotetext{
*Sponsoring body: IUPAC Inorganic Chemistry Division, Commission on Isotopic Abundances and Atomic Weights: see more details on p. 1076.

‡Corresponding author: mwieser@ucalgary.ca
} 


\section{INTRODUCTION}

Comprehensive tables of recommended atomic-weight values for use in science, industry, and commerce began with F. W. Clarke's publication of his recalculation of the atomic weights in 1882. In 1892, the American Chemical Society appointed Clarke as a permanent one-man committee to report on a standard table of atomic weights for acceptance by the society, and he reported annually from 1893 until 1913, when he asked to be relieved of this responsibility. In 1897, the Deutsche Chemische Gesellschaft appointed a working committee to report on atomic weights. They published reports on best values and also issued an invitation to other chemistry organizations to appoint delegates to an international committee for atomic weights. The international committee's first report for 1901 was published in Chemische Berichte in 1902, and this committee continued to report annually until 1921. This committee joined the International Association of Chemical Societies in September 1913, until it was dissolved in 1919. The committee then joined the International Union of Pure and Applied Chemistry (IUPAC) in June 1920. IUPAC published the new committee's first table of atomic weights in 1925. After reorganization, the international committee began to publish annual reports in 1931 [1].

Atomic-weight values originally were considered to be constants of nature and, as such, did not have any associated uncertainties. However, in the 1951 report, the committee added a footnote to sulfur indicating that a variation factor (0.003) should be attached to its atomic-weight value to account for atomic-weight variations in naturally occurring sources of sulfur. In 1961, the committee added footnotes to account for variations in atomic weights in naturally occurring sources of a number of elements, as well as experimental measurement uncertainties. By 1967, IUPAC's Commission on Atomic Weights, as it was known then, recognized that the standard atomic-weight uncertainties of some elements $(\mathrm{H}, \mathrm{B}, \mathrm{C}, \mathrm{O}, \mathrm{Si}, \mathrm{S}$, and $\mathrm{Cu})$ could not be reduced because of variations in the mole fractions of their isotopes in normal materials [2], including some chemical reagents [3]. By a "normal" material, the IUPAC Commission on Isotopic Abundances and Atomic Weights (hereafter termed the Commission) means material from a terrestrial source that satisfies the following criteria:

"The material is a reasonably possible source for this element or its compounds in commerce, for industry or science; the material is not itself studied for some extraordinary anomaly and its isotopic composition has not been modified significantly in a geologically brief period." $[4,5]$

With improvements in analytical instrumentation during the last three decades, the number of elements with two or more isotopes with documented variations in atomic-weight values in normal materials that exceed the uncertainty of the atomic weight determined from a best measurement of isotopic abundances grew to 18 elements in the 2007 Table of Standard Atomic Weights [6]. These elements were given footnote " $\mathrm{r}$ " in the IUPAC Table of Standard Atomic Weights to indicate that a range in isotopic composition of normal material prevents a more precise standard-atomic-weight value from being given. Until the publication of the 2009 Table of Standard Atomic Weights, the Commission provided a single atomic-weight value for each element (with at least one stable isotope) along with an estimated symmetrical and expanded uncertainty. These uncertainties were always estimated by the Commission through evaluation of all the relevant published literature such that any user of the atomic-weight data would, with high probability, find the atomic weight of any element in any normal sample to be in the range indicated by the uncertainty for the recommended standard atomic weight. These values thus correspond to expanded uncertainties as now defined by the International Organization for Standards (ISO) [7], and they are generally consistent with those calculated by orthodox statistical procedures from the isotopic abundances listed in column 9 of the Table of Isotopic Composition of the Elements [8]. Beginning with the 2009 Table of Standard Atomic Weights [9], the Commission highlighted the existence of atomic-weight variations for some elements by reporting atomic-weight intervals rather than single values with expanded uncertainties. The upper and lower bounds of the atomic-weight interval for a given element define the interval within which the atomic-weight value for any given sample of 
normal material may be found (see Section 1.4). Periodically, the history of the standard atomic-weight value of each element is reviewed, emphasizing the relevant published scientific evidence upon which decisions were based $[4,5,10,11]$.

Most recently, the Commission met at the University of Calgary, Canada under the chairmanship of Dr. W. A. Brand from 27 to 28 July 2011, prior to the $46^{\text {th }}$ IUPAC General Assembly in San Juan, Puerto Rico. At this meeting, the Commission reviewed recommendations of its Subcommittee on Isotopic Abundance Measurements (SIAM), suggesting changes in the standard atomic weights of some elements based on review of published data.

\subsection{Atomic weight of an element}

The atomic mass, $m_{\mathrm{a}}$, of an unbound neutral atom of carbon- $12, m_{\mathrm{a}}\left({ }^{12} \mathrm{C}\right)$, in its nuclear and electronic ground states is $12 \mathrm{u}$ exactly, where $\mathrm{u}$ is the unified atomic mass unit. The atomic weight (also called the relative atomic mass) of isotope ${ }^{i} \mathrm{E}$ of element $\mathrm{E}$, symbol $A_{\mathrm{r}}\left({ }^{i} \mathrm{E}\right)$, in material $\mathrm{P}$ is

$$
A_{\mathrm{r}}\left({ }^{i} \mathrm{E}\right)_{\mathrm{P}}=\frac{m_{\mathrm{a}}\left({ }^{i} \mathrm{E}\right)_{\mathrm{P}}}{\frac{1}{12} m_{\mathrm{a}}\left({ }^{12} \mathrm{C}\right)}=\frac{m_{\mathrm{a}}\left({ }^{i} \mathrm{E}\right)_{\mathrm{P}}}{\mathrm{u}}
$$

Thus, the atomic mass of ${ }^{12} \mathrm{C}$ is $12 \mathrm{u}$, and the atomic weight of ${ }^{12} \mathrm{C}$ is 12 exactly. All other atomic weight values are ratios to the ${ }^{12} \mathrm{C}$ standard value and thus are dimensionless numbers. The atomic weight of element $\mathrm{E}, A_{\mathrm{r}}(\mathrm{E})$, in a material $\mathrm{P}$ is determined from the relation

$$
A_{\mathrm{r}}(\mathrm{E})_{\mathrm{P}}=\sum\left[x\left({ }^{i} \mathrm{E}\right)_{\mathrm{P}} \times A_{\mathrm{r}}\left({ }^{i} \mathrm{E}\right)\right]
$$

where $x\left({ }^{i} \mathrm{E}\right)_{\mathrm{P}}$ is the mole fraction of isotope ${ }^{i} \mathrm{E}$ in material $\mathrm{P}$ (also called the isotopic abundance). The summation is over all stable isotopes of the element plus selected radioactive isotopes (having relatively long half-lives and characteristic terrestrial isotopic compositions) of the element.

The atomic weight, $A_{\mathrm{r}}(\mathrm{E})$, of element $\mathrm{E}$ in a material can be determined from knowledge of the atomic masses of the isotopes of that element and the corresponding mole fractions of the isotopes of that element in the material. In contrast to the atomic weight of an element in any given material, the standard atomic weight is a quantity that represents the atomic weights of an element in normal terrestrial materials and, therefore, must be given with larger uncertainty for some elements than the measured atomic weight in any given material. Isotopes contributing to the determination of the atomic weight of an element include (1) all stable isotopes (not known to be radioactive), of which there are 256, and (2) selected radioactive isotopes that have relatively long half-lives and characteristic terrestrial isotopic compositions, of which there are 32. A radioactive isotope of an element is said to have a characteristic terrestrial isotopic composition [12] if it contributes significantly and reproducibly to the determination of the standard atomic weight of the element in normal materials. There are 19 elements that have only one stable isotope (Be, F, Na, Al, P, Sc, Mn, Co, As, Y, Nb, Rh, I, Cs, Pr, Tb, Ho, Tm, and $\mathrm{Au}$ ). The standard atomic weight of each of these elements is derived from the atomic mass of its single stable isotope with expansion of the reported atomic-mass uncertainty to minimize future changes in the atomic weights. For elements in normal materials with no stable isotope or with no radioactive isotope with a characteristic terrestrial isotopic composition, no standard atomic weight can be determined and no value is provided in the Table of Standard Atomic Weights for these elements. The majority of the elements have two or more stable isotopes, in which case the atomic weight of an element in a material is the abundance-weighted sum of the atomic masses of its isotopes. 


\section{2 "Best measurement" of the isotopic abundances of an element}

For several decades, the isotopic abundances of many elements with two or more stable isotopes have been measured with increasing accuracy (decreasing measurement uncertainty) by means of mass spectrometry. As a result, the uncertainty in atomic-weight measurements, $U\left[A_{\mathrm{r}}(\mathrm{E})\right]$, has improved substantially. The Commission regularly evaluates reports of isotopic abundances to select the "best measurement" of the isotopic abundances of an element in a specified material. The best measurement is defined as a set of analyses of the isotope-amount ratio or isotope-number ratio of an element in a well-characterized, representative material with small combined uncertainty. To be considered by the Commission for evaluation, reports must be published in peer-reviewed literature, and the results should be given with sufficient detail so that the Commission can reconstruct the uncertainty budget in its various components, including sample preparation, analysis of isotope-amount or isotope-number ratios, and data handling. Criteria used to evaluate a "best measurement" include:

1. The extent to which measurement uncertainties of random and systematic nature have been assessed and documented in the report. The Commission seeks evidence that mass-spectrometer linearity, mass-spectrometric fractionation of ions of varying masses, memory, baseline, interferences among ions, sample purity and preparation effects, and statistical assessment of data were carried out properly. Preference is given to measurements that are fully calibrated with synthetic mixtures of isotopes of the element of interest, covering the isotopic-abundance variations of normal materials over the interval of the masses of the isotopes in the material being analyzed.

2. The relevance and availability of the analyzed material for the scientific community involved in isotopic measurements and calibrations. Preference is given to analyses of chemically stable materials that are distributed internationally as isotopic reference materials by national or international measurement institutes, or to isotopically unfractionated representatives of homogeneous terrestrial materials.

The Commission has determined that new, calibrated isotopic-composition measurements could improve substantially the standard atomic-weight values of a number of elements that have relatively large uncertainties. Such elements include Gd, Hf, Pd, and Sm.

\subsection{Categorization of elements by their atomic-weight and isotopic-composition variations}

Because variation in isotopic composition of an element impacts its atomic weight, the Commission has undertaken assessments of variations of isotopic compositions in the published literature, both through its former Subcommittee on Natural Isotopic Fractionation and through subsequent IUPAC projects.

All known elements can be categorized according to the following constraints on their standard atomic weights:

1. Elements with no stable isotope and with no radioactive isotope having a characteristic terrestrial isotopic composition in normal materials (e.g., radon). No standard atomic weight can be determined, and no value is provided in the Table of Standard Atomic weights for these elements.

2. Elements with one stable isotope (e.g., sodium). The standard atomic weight is derived from the atomic mass of its stable isotope [13-15].

3. Elements with two or more isotopes having no documented evidence of variation in atomic weight for normal materials, or elements that have not been evaluated for variation in isotopic composition by an IUPAC project (e.g., tungsten).

4. Elements with two or more isotopes having known variations in atomic weight in normal materials, but these variations do not exceed the evaluated measurement uncertainty of the atomic weight derived from the best measurement of the isotopic abundances of an element (e.g., molybdenum). 
5. Elements with two or more isotopes having known variations in atomic weight in normal materials that exceed the uncertainty of the atomic weight derived from a best measurement of isotopic abundances, but not yet assigned an atomic-weight interval by the Commission (e.g., copper).

6. Elements with two or more isotopes having known variations in atomic weight in normal materials that exceed the uncertainty of the atomic weight derived from a best measurement of isotopic abundances and having upper and lower atomic-weight bounds determined by the Commission from evaluated, peer-reviewed, published data (e.g., carbon) (Fig. 1).

Elements in category 3 may enter category 4 as more accurate isotopic-abundance measurements are published. Similarly, elements in category 4 can advance to category 5 as best-measurement results improve. Elements in category 5 can advance to category 6 as the Commission completes evaluations and assigns intervals. The Commission uses the footnote " $\mathrm{r}$ " to identify elements in category 5 for which the standard-atomic-weight uncertainty has been expanded to account for known atomic-weight variability. Graphical plots of isotopic-abundance variation and atomic-weight variation were published previously for 15 such elements: $\mathrm{H}, \mathrm{Li}, \mathrm{B}, \mathrm{C}, \mathrm{N}, \mathrm{O}, \mathrm{Mg}, \mathrm{Si}, \mathrm{S}, \mathrm{Cl}, \mathrm{Ca}, \mathrm{Cr}, \mathrm{Fe}, \mathrm{Cu}$, and Tl [16,17]. The Commission uses the footnote "g" to identify chemical elements for which the recommended standard atomic weight and its associated uncertainty do not include all known variations. For example, some elements are anomalously enriched in fissionogenic or nucleogenic isotopes at the Oklo natural nuclear reactor site in Gabon, Africa, and their atomic weights in those materials are not included in the determination of the standard atomic weight. For elements in category 3 to 6 elements, the Commission uses the footnote " $m$ " to identify those for which the standard atomic weight and its associated uncertainty in commercially available material do not include variations due to undisclosed or inadvertent isotopic fractionation. Minor periodic changes to the standard-atomic-weight values and uncertainties result from improved measurements of the atomic masses, and these changes primarily affect category 2 elements.

\subsection{Atomic-weight intervals}

Atomic weights calculated from published variations in isotopic compositions for some elements can span relatively large intervals. For example, the atomic weight of carbon in normal materials spans the interval from 12.0096 to 12.0116 (Fig. 1), whereas the uncertainty of the atomic weight calculated from the best measurement of the isotopic abundance of carbon is approximately 30 times smaller $[8,18]$; $A_{\mathrm{r}}(\mathrm{C})=12.01109(3)$. The span of atomic-weight values in normal materials is termed the interval. The interval $[a, b]$ is the set of values $x$ for which $a \leq x \leq b$, where $b>a$ and where $a$ and $b$ are the lower and upper bounds, respectively [19]. Neither the upper nor lower bounds have any uncertainty associated with them; each is a considered decision by the Commission based on professional evaluation and judgment. Writing the standard atomic weight of carbon as "[12.0096, 12.0116]" indicates that its atomic weight in any normal material will be greater than or equal to 12.0096 and will be less than or equal to 12.0116. Thus, the atomic-weight interval is said to encompass atomic-weight values of all normal materials. The range of an interval is the difference between $b$ and $a$, that is, $b-a$ [19]; thus, the range of the atomic-weight interval of carbon is calculated as $12.0116-12.0096=0.0020$. The interval designation does not imply any statistical distribution of atomic-weight values between the lower and upper bounds (e.g., the mean of $a$ and $b$ is not necessarily the most likely value). Similarly, the interval does not convey a simple statistical representation of uncertainty. In the 2009 Table of Standard Atomic Weights, the interval was signified by $[a ; b]$. With the 2012 correction of International Vocabulary of Metrology - Basic and General Concepts and Associated Terms [19], the symbol for expressing an interval in English language publications has changed from $[a ; b]$ to $[a, b]$.

The lower bound of an atomic-weight interval is determined from the lowest atomic weight determined by the Commission's evaluations, and it takes into account the uncertainty of the measurement. Commonly, an isotope-delta measurement is the basis for the determination of the bound $[15,16]$. In 


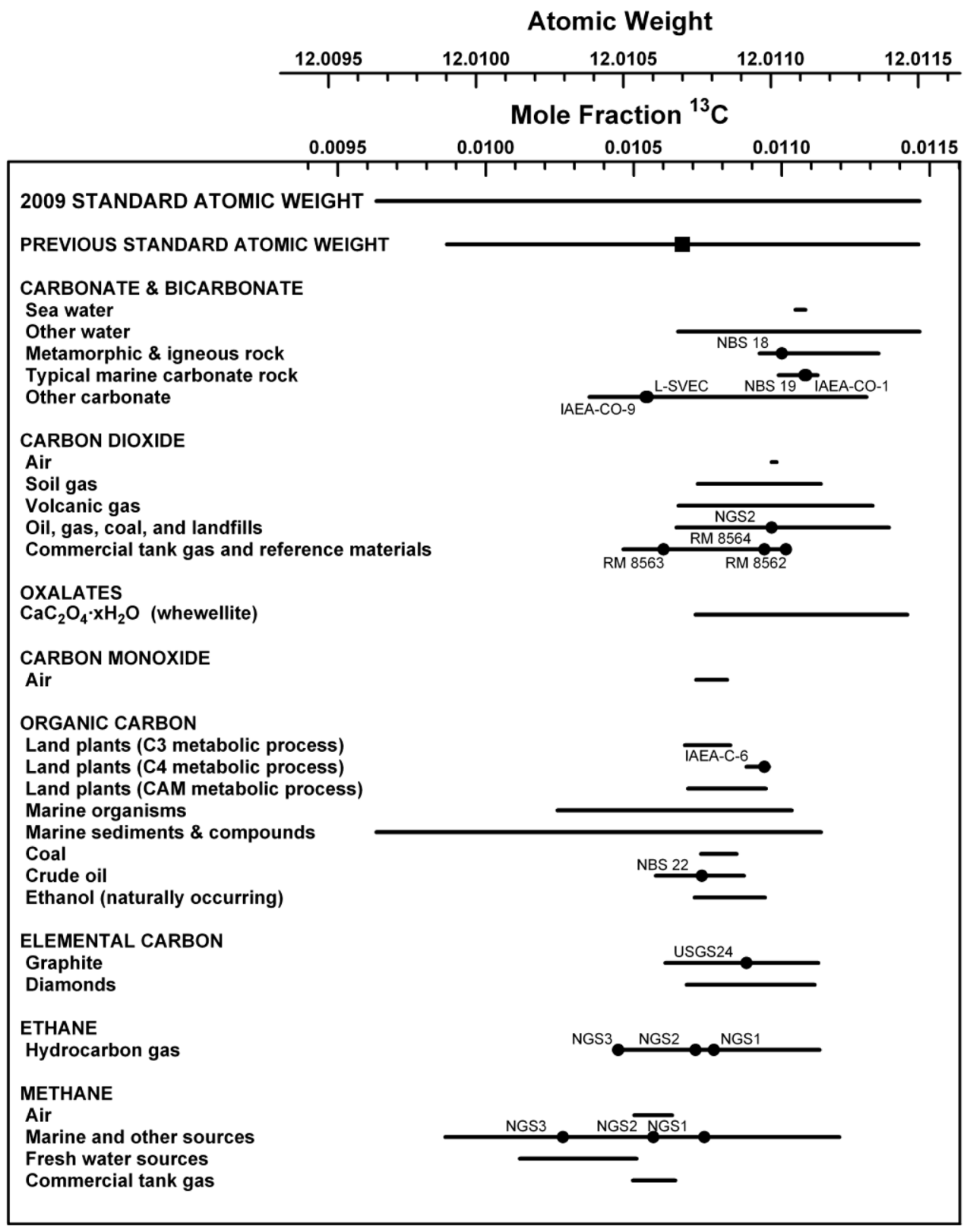

Fig. 1 Variation in atomic weight with isotopic composition of selected carbon-bearing materials (modified from $[16,17])$. Isotopic reference materials are designated by solid black circles. The 2009 standard atomic weight of carbon is expressed as an interval [12.0096, 12.0116] [9]. The previous (2007) standard atomic weight of carbon [6] was 12.0107(8). The atomic-weight uncertainty of the "best measurement" of isotopic abundance [16,17] is approximately \pm 0.000027 , which is about 30 times smaller than the uncertainty of the 2007 standard atomic weight [6]. 
addition to the uncertainty in the isotope-delta value [20], the uncertainty in the atomic weight of the material anchoring the isotope-delta scale also must be taken into account. The latter is the uncertainty in relating a delta scale to an atomic-weight scale $[16,17]$. If material $\mathrm{P}$ is the normal material having the lowest atomic weight of element $\mathrm{E}$, then

$$
\text { lower bound = lowest } A_{\mathrm{r}}(\mathrm{E})_{\mathrm{P}}-U\left[A_{\mathrm{r}}(\mathrm{E})\right]_{\mathrm{P}}
$$

where $U\left[A_{\mathrm{r}}(\mathrm{E})\right]_{\mathrm{P}}$ is the combined uncertainty that incorporates the uncertainty in the measurement of the delta value of material $\mathrm{P}$ and the uncertainty in relating the delta-value scale to the atomic-weight scale. For example, consider the lower bound for carbon. The material with the lowest measured ${ }^{13} \mathrm{C}$ abundance is crocetane (2,6,11,15-tetramethylhexadecane), produced at cold seeps of the eastern Aleutian subduction zone [21]. For this material, $A_{\mathrm{r}}(\mathrm{C})=12.009662$, where the atomic weight is determined from an isotope-delta value $[16,17]$. The uncertainty of the delta measurement is equivalent to an uncertainty in the atomic weight of 0.000003 . The uncertainty in relating the carbon-delta scale to its atomic-weight scale corresponds to an atomic-weight uncertainty of 0.000027 . Therefore, the combined uncertainty in the lowest atomic-weight value of carbon is $U\left[A_{\mathrm{r}}(\mathrm{E})\right]_{\mathrm{P}}=\left(0.000003^{2}+\right.$ $\left.0.000027^{2}\right)^{1 / 2}=0.000027$ and the lower bound $=12.009662-0.000027=12.009635$.

The upper bound is calculated in an equivalent manner except that the combined uncertainty is added to the atomic-weight value of the material $\mathrm{P}$ with the highest measured atomic weight.

upper bound $=$ highest $A_{\mathrm{r}}(\mathrm{E})_{\mathrm{P}}+U\left[A_{\mathrm{r}}(\mathrm{E})\right]_{\mathrm{P}}$

For the example of carbon, the material with the highest ${ }^{13} \mathrm{C}$-abundance fraction is deep-sea pore water, and it has an atomic-weight value of 12.011505 . The component of uncertainty in the atomic-weight value of this material attributed to the uncertainty in the delta-value determination is 0.000003 . As with the lower bound, the uncertainty in relating the carbon-delta scale to its atomic-weight scale results in an atomic-weight uncertainty of 0.000027 . Thus, the upper bound $=12.011505+\left(0.000003^{2}+\right.$ $\left.0.000027^{2}\right)^{1 / 2}=12.011532$.

The uncertainties of the delta measurements and the uncertainty of the atomic weight derived from the best measurement of isotopic abundances constrain the number of significant digits in the atomic-weight values of the upper and lower bounds. For carbon, the fifth digit after the decimal point is uncertain because of the uncertainty value of 0.000027 . Therefore, the number of significant digits in the atomic-weight value is reduced to four figures after the decimal point. The Commission may recommend additional conservatism and reduce the number of significant figures further. For the lower bound of carbon, 12.009635 is truncated to 12.0096. For an upper bound, the trailing digit is increased to ensure the atomic-weight interval encompasses the atomic-weight values of all normal materials. In the case of carbon, the upper bound is adjusted from 12.011532 to 12.0116 to express four digits after the decimal point. The lower and upper bounds are evaluated so that the number of significant digits in each is identical. If a value ends with a zero, it may need to be included in the value to express the required number of digits. The following are examples of lower and upper atomic-weight bounds for oxygen that could be published by the Commission in its various tables.
15.99903
15.99977
Unabridged Table of Standard Atomic Weights
15.9990
15.9998
Abridged to six significant figures
$15.999 \quad 16.000$
Table of Standard Atomic Weights Abridged to Five Significant Digits
15.99 16.00 Table of Standard Atomic Weights Abridged to Four Significant Digits

Rules and comments on determining values of atomic-weight intervals of elements having two or more stable isotopes include:

1. The variation in atomic-weight values of an element is termed an atomic-weight "interval" with the symbol $[a, b]$, where $a$ and $b$ are the lower and upper bounds, respectively, of the interval; thus, for element $\mathrm{E}, a \leq A_{\mathrm{r}}(\mathrm{E}) \leq b$. 
2. The standard atomic weight of an element expressed as an interval, $[a, b]$, should not be expressed as the average of $a$ and $b$ with an associated uncertainty equal to half of the difference between $b$ and $a$. For example, $A_{\mathrm{r}}(\mathrm{C})=[12.0096,12.0116]$ and should not be expressed as $A_{\mathrm{r}}(\mathrm{C})=$ 12.0106(48).

3. The atomic-weight interval encompasses atomic-weight values of all normal materials.

4. The atomic-weight interval is the standard atomic weight.

5. The atomic-weight interval and range should not be confused. The atomic-weight range is $b-a$, where $a$ and $b$ are the lower and upper bounds, respectively.

6. The lower and upper bounds commonly are determined from the lowest and highest isotope-delta values of normal materials, taking into account uncertainties of the isotope-delta measurements and uncertainty in relating the isotope-delta scale to the atomic-weight scale of an element.

7. Both lower and upper bounds are consensus values, and neither has any uncertainty associated with it.

8. The number of significant digits in the lower and upper bounds are adjusted so that uncertainty in either of the isotope-delta measurements or in the uncertainty relating the delta scale to the atomic-weight scale do not impact the lower and upper bounds.

9. The number of significant digits in the lower and upper bounds should be identical. A zero as a trailing digit in a value may be needed and is acceptable.

10. The atomic-weight interval is selected conservatively so that changes in the Table of Standard Atomic Weights are needed infrequently.

11. The atomic-weight interval is given as precisely as possible and should have as many digits as possible, consistent with the previously stated rules.

12. Values of atomic-weight intervals are updated in the Table of Standard Atomic Weights by the Commission following completion of an IUPAC project reviewing the published literature for peer-reviewed, isotopic-abundance data.

13. If the standard-atomic-weight uncertainty for an element has been expanded because of reported variation in isotopic composition in normal materials, but the Commission has not assigned an interval, a footnote " $\mathrm{r}$ " is retained in the Table of Standard Atomic Weights until the Commission completes an evaluation and determines lower and upper bounds from published data.

\section{TABLES OF STANDARD ATOMIC WEIGHTS IN ALPHABETIC AND ATOMIC-NUMBER ORDER}

The Table of Standard Atomic Weights 2011 is given in alphabetical order of the English names in Table 1 and in order of atomic number in Table 2. The standard atomic weights reported in Tables 1 and 2 are for atoms in their nuclear and electronic ground states. With minor exceptions covered by footnotes, the Table of Standard Atomic Weights is intended to apply to all normal terrestrial materials as well as materials in commerce, samples found in laboratories involved in chemical investigations, and samples in technological applications. The Table of Standard Atomic Weights does not apply to extraterrestrial materials or to materials with deliberately altered isotopic compositions.

To indicate that standard atomic weights of elements with two or more stable isotopes are not constants of nature, the Table of Standard Atomic Weights 2011 lists atomic-weight intervals for the standard atomic weights of 12 such elements (B, Br, C, Cl, H, Li, Mg, N, O, S, Si, and Tl). Graphical plots showing isotopic abundances and atomic weights of various specimens are provided for $\mathrm{C}, \mathrm{Br}$, and $\mathrm{Mg}$ in this report. Similar graphical plots for $\mathrm{B}, \mathrm{Cl}, \mathrm{H}, \mathrm{Li}, \mathrm{N}, \mathrm{O}, \mathrm{S}, \mathrm{Si}$, and $\mathrm{Tl}$ may be found in the Table of Standard Atomic Weights 2009 [6].

For elements within categories 2 to 5 (see Section 1.4 for category descriptions), a decisional uncertainty, $U\left[A_{\mathrm{r}}(\mathrm{E})\right]$, is given in parentheses following the last significant figure to which it is attributed. The interval $A_{\mathrm{r}}(\mathrm{E})-U\left[A_{\mathrm{r}}(\mathrm{E})\right]$ to $A_{\mathrm{r}}(\mathrm{E})+U\left[A_{\mathrm{r}}(\mathrm{E})\right]$ may be expected to encompass atomic-weight values of normal materials. 
Table 1 Standard atomic weights 2011.

[Scaled to $A_{\mathrm{r}}\left({ }^{12} \mathrm{C}\right)=12$, where ${ }^{12} \mathrm{C}$ is a neutral atom in its nuclear and electronic ground state.]

The atomic weights, $A_{\mathrm{r}}(\mathrm{E})$, of many elements vary because of variations in the abundances of their isotopes in normal materials. For 12 such elements, an atomic-weight interval is given with the symbol $[a, b]$ to denote the set of atomic-weight values in normal materials; thus, $a \leq A_{\mathrm{r}}(\mathrm{E}) \leq b$ for element $\mathrm{E}$. The symbols $a$ and $b$ denote the bounds of the interval $[a, b]$. If a more accurate $A_{\mathrm{r}}(\mathrm{E})$ value for a specific material is required, it should be determined. For 72 elements, $A_{\mathrm{r}}(\mathrm{E})$ values and their evaluated uncertainties (in parentheses, following the last significant digit to which they are attributed) are given. Names of elements with atomic number 113, 115, 117, and 118 are provisional; they have been reported in the peer-reviewed, scientific literature, but they have not yet been named by IUPAC.

\begin{tabular}{|c|c|c|c|c|c|}
\hline \multicolumn{6}{|c|}{ Alphabetic order in English } \\
\hline Element name & Symbol & Atomic number & $\begin{array}{c}\text { Standard } \\
\text { atomic weight }\end{array}$ & $\begin{array}{c}\text { See also } \\
\text { Table/Figure }\end{array}$ & Footnotes \\
\hline actinium* & Ac & 89 & & & \\
\hline aluminium (aluminum) & $\mathrm{Al}$ & 13 & $26.9815386(8)$ & & \\
\hline americium* & $\mathrm{Am}$ & 95 & & & \\
\hline antimony & $\mathrm{Sb}$ & 51 & $121.760(1)$ & & $\mathrm{g}$ \\
\hline argon & $\mathrm{Ar}$ & 18 & $39.948(1)$ & & $\mathrm{g}$ \\
\hline arsenic & As & 33 & $74.92160(2)$ & & \\
\hline astatine* & At & 85 & & & \\
\hline barium & $\mathrm{Ba}$ & 56 & $137.327(7)$ & & \\
\hline berkelium* & $\mathrm{Bk}$ & 97 & & & \\
\hline beryllium & $\mathrm{Be}$ & 4 & $9.012182(3)$ & & \\
\hline bismuth* & $\mathrm{Bi}$ & 83 & $208.98040(1)$ & & \\
\hline bohrium* & $\mathrm{Bh}$ & 107 & & & \\
\hline boron & B & 5 & {$[10.806,10.821]$} & $6 / 5$ in ref. $[8]$ & $\mathrm{m}$ \\
\hline bromine & $\mathrm{Br}$ & 35 & {$[79.901,79.907]$} & $6 / 2$ & \\
\hline cadmium & $\mathrm{Cd}$ & 48 & $112.411(8)$ & & $\mathrm{g}$ \\
\hline caesium (cesium) & Cs & 55 & $132.9054519(2)$ & & \\
\hline calcium & $\mathrm{Ca}$ & 20 & $40.078(4)$ & & $\mathrm{g}$ \\
\hline californium* & $\mathrm{Cf}$ & 98 & & & \\
\hline carbon & $\mathrm{C}$ & 6 & {$[12.0096,12.0116]$} & $6 / 1$ & \\
\hline cerium & $\mathrm{Ce}$ & 58 & $140.116(1)$ & & $\mathrm{g}$ \\
\hline chlorine & $\mathrm{Cl}$ & 17 & {$[35.446,35.457]$} & 6/10 in ref. [8] & $\mathrm{m}$ \\
\hline chromium & $\mathrm{Cr}$ & 24 & $51.9961(6)$ & & \\
\hline cobalt & Co & 27 & $58.933195(5)$ & & \\
\hline copernicium* & $\mathrm{Cn}$ & 112 & & & \\
\hline copper & $\mathrm{Cu}$ & 29 & $63.546(3)$ & & $\mathrm{r}$ \\
\hline curium* & $\mathrm{Cm}$ & 96 & & & \\
\hline darmstadtium* & Ds & 110 & & & \\
\hline dubnium* & $\mathrm{Db}$ & 105 & & & \\
\hline dysprosium & Dy & 66 & $162.500(1)$ & & $\mathrm{g}$ \\
\hline einsteinium* & Es & 99 & & & \\
\hline erbium & Er & 68 & $167.259(3)$ & & $\mathrm{g}$ \\
\hline europium & $\mathrm{Eu}$ & 63 & $151.964(1)$ & & $\mathrm{g}$ \\
\hline fermium* & $\mathrm{Fm}$ & 100 & & & \\
\hline flerovium* & $\mathrm{Fl}$ & 114 & & & \\
\hline fluorine & $\mathrm{F}$ & 9 & $18.9984032(5)$ & & \\
\hline francium* & $\mathrm{Fr}$ & 87 & & & \\
\hline gadolinium & $\mathrm{Gd}$ & 64 & $157.25(3)$ & & $\mathrm{g}$ \\
\hline gallium & $\mathrm{Ga}$ & 31 & 69.723(1) & & \\
\hline
\end{tabular}

(continues on next page) 
Table 1 (Continued).

\begin{tabular}{|c|c|c|c|c|c|}
\hline \multicolumn{6}{|c|}{ Alphabetic order in English } \\
\hline Element name & Symbol & Atomic number & $\begin{array}{c}\text { Standard } \\
\text { atomic weight }\end{array}$ & $\begin{array}{c}\text { See also } \\
\text { Table/Figure }\end{array}$ & Footnotes \\
\hline germanium & $\mathrm{Ge}$ & 32 & $72.630(8)$ & & \\
\hline gold & $\mathrm{Au}$ & 79 & $196.966569(4)$ & & \\
\hline hafnium & Hf & 72 & $178.49(2)$ & & \\
\hline hassium* & Hs & 108 & & & \\
\hline helium & $\mathrm{He}$ & 2 & $4.002602(2)$ & & $\mathrm{g}$ \\
\hline holmium & Ho & 67 & $164.93032(2)$ & & \\
\hline hydrogen & $\mathrm{H}$ & 1 & {$[1.00784,1.00811]$} & $6 / 3$ in ref. [8] & $\mathrm{m}$ \\
\hline indium & In & 49 & $114.818(1)$ & & \\
\hline iodine & I & 53 & $126.90447(3)$ & & \\
\hline iridium & $\mathrm{Ir}$ & 77 & $192.217(3)$ & & \\
\hline iron & $\mathrm{Fe}$ & 26 & $55.845(2)$ & & \\
\hline krypton & $\mathrm{Kr}$ & 36 & $83.798(2)$ & & $\mathrm{g} \mathrm{m}$ \\
\hline lanthanum & $\mathrm{La}$ & 57 & $138.90547(7)$ & & $\mathrm{g}$ \\
\hline lawrencium* & $\mathrm{Lr}$ & 103 & & & \\
\hline lead & $\mathrm{Pb}$ & 82 & $207.2(1)$ & & $\begin{array}{ll}\mathrm{g} & \mathrm{r}\end{array}$ \\
\hline lithium & $\mathrm{Li}$ & 3 & {$[6.938,6.997]$} & $6 / 4$ in ref. [8] & $\mathrm{m}$ \\
\hline livermorium* & $\mathrm{Lv}$ & 116 & & & \\
\hline lutetium & $\mathrm{Lu}$ & 71 & $174.9668(1)$ & & $\mathrm{g}$ \\
\hline magnesium & $\mathrm{Mg}$ & 12 & {$[24.304,24.307]$} & $6 / 3$ & \\
\hline manganese & $\mathrm{Mn}$ & 25 & $54.938045(5)$ & & \\
\hline meitnerium* & Mt & 109 & & & \\
\hline mendelevium* & Md & 101 & & & \\
\hline mercury & $\mathrm{Hg}$ & 80 & $200.592(3)$ & & \\
\hline molybdenum & Mo & 42 & $95.96(2)$ & & $\mathrm{g}$ \\
\hline neodymium & $\mathrm{Nd}$ & 60 & $144.242(3)$ & & $\mathrm{g}$ \\
\hline neon & $\mathrm{Ne}$ & 10 & 20.1797(6) & & $\mathrm{g} \mathrm{m}$ \\
\hline neptunium* & $\mathrm{Np}$ & 93 & & & \\
\hline nickel & $\mathrm{Ni}$ & 28 & $58.6934(4)$ & & $\mathrm{r}$ \\
\hline niobium & $\mathrm{Nb}$ & 41 & $92.90638(2)$ & & \\
\hline nitrogen & $\mathrm{N}$ & 7 & {$[14.00643,14.00728]$} & $6 / 6$ in ref. [8] & \\
\hline nobelium* & No & 102 & & & \\
\hline osmium & Os & 76 & $190.23(3)$ & & $\mathrm{g}$ \\
\hline oxygen & $\mathrm{O}$ & 8 & {$[15.99903,15.99977]$} & $6 / 7$ in ref. [8] & \\
\hline palladium & $\mathrm{Pd}$ & 46 & $106.42(1)$ & & $\mathrm{g}$ \\
\hline phosphorus & $\mathrm{P}$ & 15 & $30.973762(2)$ & & \\
\hline platinum & $\mathrm{Pt}$ & 78 & $195.084(9)$ & & \\
\hline plutonium* & $\mathrm{Pu}$ & 94 & & & \\
\hline polonium* & Po & 84 & & & \\
\hline potassium & $\mathrm{K}$ & 19 & $39.0983(1)$ & & \\
\hline praseodymium & $\operatorname{Pr}$ & 59 & $140.90765(2)$ & & \\
\hline promethium* & $\mathrm{Pm}$ & 61 & & & \\
\hline protactinium* & $\mathrm{Pa}$ & 91 & $231.03588(2)$ & & \\
\hline radium $*$ & $\mathrm{Ra}$ & 88 & & & \\
\hline radon* & $\mathrm{Rn}$ & 86 & & & \\
\hline roentgenium* & $\mathrm{Rg}$ & 111 & & & \\
\hline rhenium & $\mathrm{Re}$ & 75 & $186.207(1)$ & & \\
\hline rhodium & $\mathrm{Rh}$ & 45 & $102.90550(2)$ & & \\
\hline
\end{tabular}

(continues on next page) 
Table 1 (Continued).

\begin{tabular}{|c|c|c|c|c|c|}
\hline \multicolumn{6}{|c|}{ Alphabetic order in English } \\
\hline Element name & Symbol & Atomic number & $\begin{array}{c}\text { Standard } \\
\text { atomic weight }\end{array}$ & $\begin{array}{c}\text { See also } \\
\text { Table/Figure }\end{array}$ & Footnotes \\
\hline rubidium & $\mathrm{Rb}$ & 37 & $85.4678(3)$ & & $\mathrm{g}$ \\
\hline ruthenium & $\mathrm{Ru}$ & 44 & $101.07(2)$ & & $\mathrm{g}$ \\
\hline rutherfordium* & $\mathrm{Rf}$ & 104 & & & \\
\hline samarium & $\mathrm{Sm}$ & 62 & $150.36(2)$ & & $\mathrm{g}$ \\
\hline scandium & $\mathrm{Sc}$ & 21 & $44.955912(6)$ & & \\
\hline seaborgium* & $\mathrm{Sg}$ & 106 & & & \\
\hline selenium & $\mathrm{Se}$ & 34 & $78.96(3)$ & & $\mathrm{r}$ \\
\hline silicon & $\mathrm{Si}$ & 14 & {$[28.084,28.086]$} & $6 / 8$ in ref. [8] & \\
\hline silver & $\mathrm{Ag}$ & 47 & $107.8682(2)$ & & $\mathrm{g}$ \\
\hline sodium & $\mathrm{Na}$ & 11 & $22.98976928(2)$ & & \\
\hline strontium & $\mathrm{Sr}$ & 38 & $87.62(1)$ & & $\mathrm{g}$ \\
\hline sulfur & $\mathrm{S}$ & 16 & {$[32.059,32.076]$} & $6 / 9$ in ref. [8] & \\
\hline tantalum & $\mathrm{Ta}$ & 73 & $180.94788(2)$ & & \\
\hline technetium* & $\mathrm{Tc}$ & 43 & & & \\
\hline tellurium & $\mathrm{Te}$ & 52 & $127.60(3)$ & & $\mathrm{g}$ \\
\hline terbium & $\mathrm{Tb}$ & 65 & $158.92535(2)$ & & \\
\hline thallium & $\mathrm{Tl}$ & 81 & {$[204.382,204.385]$} & 6/11 in ref. [8] & \\
\hline thorium* & Th & 90 & $232.03806(2)$ & & $\mathrm{g}$ \\
\hline thulium & $\mathrm{Tm}$ & 69 & $168.93421(2)$ & & \\
\hline $\operatorname{tin}$ & $\mathrm{Sn}$ & 50 & $118.710(7)$ & & $\mathrm{g}$ \\
\hline titanium & $\mathrm{Ti}$ & 22 & 47.867(1) & & \\
\hline tungsten & W & 74 & 183.84(1) & & \\
\hline ununoctium* & Uuo & 118 & & & \\
\hline ununpentium* & Uup & 115 & & & \\
\hline ununtrium* & Uut & 113 & & & \\
\hline ununseptium* & Uus & 117 & & & \\
\hline uranium* & $\mathrm{U}$ & 92 & 238.02891(3) & & $\mathrm{g} \mathrm{m}$ \\
\hline vanadium & $\mathrm{V}$ & 23 & $50.9415(1)$ & & \\
\hline xenon & $\mathrm{Xe}$ & 54 & 131.293(6) & & $\mathrm{g} \mathrm{m}$ \\
\hline ytterbium & $\mathrm{Yb}$ & 70 & $173.054(5)$ & & $\mathrm{g}$ \\
\hline yttrium & $\mathrm{Y}$ & 39 & $88.90585(2)$ & & \\
\hline zinc & $\mathrm{Zn}$ & 30 & $65.38(2)$ & & $\mathrm{r}$ \\
\hline zirconium & $\mathrm{Zr}$ & 40 & $91.224(2)$ & & $\mathrm{g}$ \\
\hline
\end{tabular}

*Element has no stable isotopes. One or more representative isotopes are given in Table 3 with the appropriate relative atomic mass and half-life. However, four such elements ( $\mathrm{Bi}, \mathrm{Th}, \mathrm{Pa}$, and $\mathrm{U}$ ) do have a characteristic terrestrial isotopic composition, and for these elements, standard atomic weights are tabulated.

g Geological materials are known in which the element has an isotopic composition outside the limits for normal material. The difference between the atomic weight of the element in such materials and that given in the table may exceed the stated uncertainty.

$\mathrm{m} \quad$ Modified isotopic compositions may be found in commercially available material because the material has been subjected to an undisclosed or inadvertent isotopic fractionation. Substantial deviations in atomic weight of the element from that given in the table can occur.

$\mathrm{r} \quad$ Range in isotopic composition of normal terrestrial material prevents a more precise $A_{\mathrm{r}}(\mathrm{E})$ being given; the tabulated $A_{\mathrm{r}}(\mathrm{E})$ value and uncertainty should be applicable to normal material. 
Table 2 Standard atomic weights 2011.

[Scaled to $A_{\mathrm{r}}\left({ }^{12} \mathrm{C}\right)=12$, where ${ }^{12} \mathrm{C}$ is a neutral atom in its nuclear and electronic ground state.]

The atomic weights, $A_{\mathrm{r}}(\mathrm{E})$, of many elements vary because of variations in the abundances of their isotopes in normal materials. For 12 such elements, an atomic-weight interval is given with the symbol $[a, b]$ to denote the set of atomic-weight values in normal materials; thus, $a \leq A_{\mathrm{r}}(\mathrm{E}) \leq b$ for element $\mathrm{E}$. The symbols $a$ and $b$ denote the bounds of the interval $[a, b]$. If a more accurate $A_{\mathrm{r}}(\mathrm{E})$ value for a specific material is required, it should be determined. For 72 elements, $A_{\mathrm{r}}(\mathrm{E})$ values and their evaluated uncertainties (in parentheses, following the last significant digit to which they are attributed) are given. Names of elements with atomic number 113, 115, 117, and 118 are provisional; they have been reported in the peer-reviewed, scientific literature, but they have not yet been named by IUPAC.

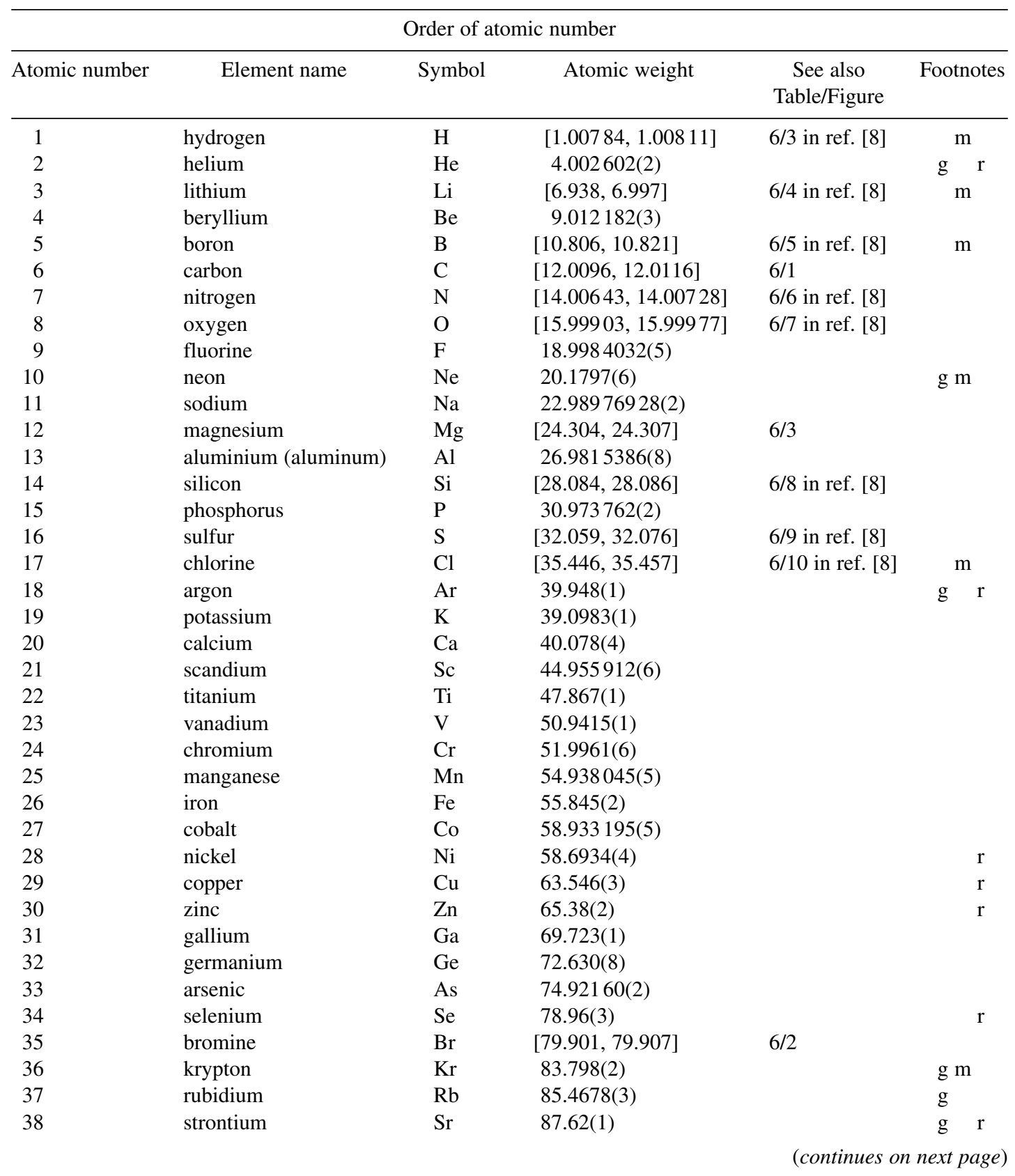


Table 2 (Continued).

\begin{tabular}{|c|c|c|c|c|c|}
\hline \multicolumn{6}{|c|}{ Order of atomic number } \\
\hline Atomic number & Element name & Symbol & Atomic weight & $\begin{array}{c}\text { See also } \\
\text { Table/Figure }\end{array}$ & Footnotes \\
\hline 39 & yttrium & $\mathrm{Y}$ & $88.90585(2)$ & & \\
\hline 40 & zirconium & $\mathrm{Zr}$ & $91.224(2)$ & & $\mathrm{g}$ \\
\hline 41 & niobium & $\mathrm{Nb}$ & $92.90638(2)$ & & \\
\hline 42 & molybdenum & Mo & $95.96(2)$ & & $\mathrm{g}$ \\
\hline 43 & technetium* & Tc & & & \\
\hline 44 & ruthenium & $\mathrm{Ru}$ & $101.07(2)$ & & $\mathrm{g}$ \\
\hline 45 & rhodium & $\mathrm{Rh}$ & $102.90550(2)$ & & \\
\hline 46 & palladium & $\mathrm{Pd}$ & $106.42(1)$ & & $\mathrm{g}$ \\
\hline 47 & silver & $\mathrm{Ag}$ & $107.8682(2)$ & & $\mathrm{g}$ \\
\hline 48 & cadmium & $\mathrm{Cd}$ & $112.411(8)$ & & $\mathrm{g}$ \\
\hline 49 & indium & In & $114.818(1)$ & & \\
\hline 50 & tin & $\mathrm{Sn}$ & $118.710(7)$ & & $\mathrm{g}$ \\
\hline 51 & antimony & $\mathrm{Sb}$ & $121.760(1)$ & & $\mathrm{g}$ \\
\hline 52 & tellurium & $\mathrm{Te}$ & $127.60(3)$ & & $\mathrm{g}$ \\
\hline 53 & iodine & I & $126.90447(3)$ & & \\
\hline 54 & xenon & $\mathrm{Xe}$ & $131.293(6)$ & & g m \\
\hline 55 & caesium (cesium) & $\mathrm{Cs}$ & $132.9054519(2)$ & & \\
\hline 56 & barium & $\mathrm{Ba}$ & $137.327(7)$ & & \\
\hline 57 & lanthanum & $\mathrm{La}$ & $138.90547(7)$ & & $\mathrm{g}$ \\
\hline 58 & cerium & $\mathrm{Ce}$ & $140.116(1)$ & & $\mathrm{g}$ \\
\hline 59 & praseodymium & $\operatorname{Pr}$ & $140.90765(2)$ & & \\
\hline 60 & neodymium & $\mathrm{Nd}$ & $144.242(3)$ & & $\mathrm{g}$ \\
\hline 61 & promethium* & $\mathrm{Pm}$ & & & \\
\hline 62 & samarium & $\mathrm{Sm}$ & $150.36(2)$ & & $\mathrm{g}$ \\
\hline 63 & europium & $\mathrm{Eu}$ & $151.964(1)$ & & $\mathrm{g}$ \\
\hline 64 & gadolinium & Gd & $157.25(3)$ & & $\mathrm{g}$ \\
\hline 65 & terbium & $\mathrm{Tb}$ & $158.92535(2)$ & & \\
\hline 66 & dysprosium & Dy & $162.500(1)$ & & $\mathrm{g}$ \\
\hline 67 & holmium & Ho & $164.93032(2)$ & & \\
\hline 68 & erbium & $\mathrm{Er}$ & $167.259(3)$ & & $\mathrm{g}$ \\
\hline 69 & thulium & $\mathrm{Tm}$ & $168.93421(2)$ & & \\
\hline 70 & ytterbium & $\mathrm{Yb}$ & $173.054(5)$ & & $\mathrm{g}$ \\
\hline 71 & lutetium & $\mathrm{Lu}$ & $174.9668(1)$ & & $\mathrm{g}$ \\
\hline 72 & hafnium & $\mathrm{Hf}$ & $178.49(2)$ & & \\
\hline 73 & tantalum & $\mathrm{Ta}$ & $180.94788(2)$ & & \\
\hline 74 & tungsten & $\mathrm{W}$ & $183.84(1)$ & & \\
\hline 75 & rhenium & $\mathrm{Re}$ & $186.207(1)$ & & \\
\hline 76 & osmium & Os & $190.23(3)$ & & $\mathrm{g}$ \\
\hline 77 & iridium & $\mathrm{Ir}$ & $192.217(3)$ & & \\
\hline 78 & platinum & $\mathrm{Pt}$ & $195.084(9)$ & & \\
\hline 79 & gold & $\mathrm{Au}$ & $196.966569(4)$ & & \\
\hline 80 & mercury & $\mathrm{Hg}$ & $200.592(3)$ & & \\
\hline 81 & thallium & $\mathrm{Tl}$ & {$[204.382,204.385]$} & $6 / 11$ in ref. [8] & \\
\hline 82 & lead & $\mathrm{Pb}$ & $207.2(1)$ & & $\mathrm{g}$ \\
\hline 83 & bismuth* & $\mathrm{Bi}$ & $208.98040(1)$ & & \\
\hline 84 & polonium* & Po & & & \\
\hline 85 & astatine* & At & & & \\
\hline
\end{tabular}

(continues on next page) 
Table 2 (Continued).

\begin{tabular}{|c|c|c|c|c|c|}
\hline \multicolumn{6}{|c|}{ Order of atomic number } \\
\hline Atomic number & Element name & Symbol & Atomic weight & $\begin{array}{c}\text { See also } \\
\text { Table/Figure }\end{array}$ & Footnotes \\
\hline 86 & radon* & $\mathrm{Rn}$ & & & \\
\hline 87 & francium* & $\mathrm{Fr}$ & & & \\
\hline 88 & radium* & $\mathrm{Ra}$ & & & \\
\hline 89 & actinium* & Ac & & & \\
\hline 90 & thorium* & Th & $232.03806(2)$ & & $\mathrm{g}$ \\
\hline 91 & protactinium* & $\mathrm{Pa}$ & $231.03588(2)$ & & \\
\hline 92 & uranium* & $\mathrm{U}$ & $238.02891(3)$ & & $\mathrm{g} \mathrm{m}$ \\
\hline 93 & neptunium* & $\mathrm{Np}$ & & & \\
\hline 94 & plutonium* & $\mathrm{Pu}$ & & & \\
\hline 95 & americium* & $\mathrm{Am}$ & & & \\
\hline 96 & curium* & $\mathrm{Cm}$ & & & \\
\hline 97 & berkelium* & $\mathrm{Bk}$ & & & \\
\hline 98 & californium* & $\mathrm{Cf}$ & & & \\
\hline 99 & einsteinium* & Es & & & \\
\hline 100 & fermium* & Fm & & & \\
\hline 101 & mendelevium* & Md & & & \\
\hline 102 & nobelium* & No & & & \\
\hline 103 & lawrencium* & $\mathrm{Lr}$ & & & \\
\hline 104 & rutherfordium* & $\mathrm{Rf}$ & & & \\
\hline 105 & dubnium* & $\mathrm{Db}$ & & & \\
\hline 106 & seaborgium* & $\mathrm{Sg}$ & & & \\
\hline 107 & bohrium* & $\mathrm{Bh}$ & & & \\
\hline 108 & hassium* & Hs & & & \\
\hline 109 & meitnerium* & Mt & & & \\
\hline 110 & darmstadtium* & Ds & & & \\
\hline 111 & roentgenium* & $\mathrm{Rg}$ & & & \\
\hline 112 & copernicium* & $\mathrm{Cn}$ & & & \\
\hline 113 & ununtrium* & Uut & & & \\
\hline 114 & flerovium* & $\mathrm{Fl}$ & & & \\
\hline 115 & ununpentium* & Uup & & & \\
\hline 116 & livermorium* & $\mathrm{Lv}$ & & & \\
\hline 117 & ununseptium* & Uus & & & \\
\hline 118 & ununoctium* & Uuo & & & \\
\hline
\end{tabular}

*Element has no stable isotopes. One or more representative isotopes are given in Table 3 with the appropriate relative atomic mass and half-life. However, four such elements ( $\mathrm{Bi}, \mathrm{Th}, \mathrm{Pa}$, and $\mathrm{U}$ ) do have a characteristic terrestrial isotopic composition, and for these elements, standard atomic weights are tabulated.

g Geological materials are known in which the element has an isotopic composition outside the limits for normal material. The difference between the atomic weight of the element in such materials and that given in the table may exceed the stated uncertainty.

$\mathrm{m} \quad$ Modified isotopic compositions may be found in commercially available material because the material has been subjected to an undisclosed or inadvertent isotopic fractionation. Substantial deviations in atomic weight of the element from that given in the table can occur.

$\mathrm{r} \quad$ Range in isotopic composition of normal terrestrial material prevents a more precise $A_{\mathrm{r}}(\mathrm{E})$ being given; the tabulated $A_{\mathrm{r}}(\mathrm{E})$ value and uncertainty should be applicable to normal material.

For each element for which a change in the standard atomic weight is recommended, the Commission by custom makes a statement on the reason for the change and includes a list of recommended values over a period in excess of the last 100 years, which are taken from [22] and subsequent 
Commission publications. Values before the formation of the International Committee on Atomic Weights in 1900 come from [23].

Provisional names and symbols given in Tables 1 and 2 for elements with atomic numbers 113 to 118 are systematic and based on the atomic numbers of the elements as recommended by the IUPAC publication Nomenclature of Inorganic Chemistry [24]. Each systematic name and symbol will be replaced by a permanent name approved by IUPAC after the priority of discovery is established and the name suggested by the discoverers is examined, reviewed, and accepted. The systematic name is derived directly from the atomic number of the element using the following numerical roots:

$\begin{array}{lllll}1 \text { un } & 2 \text { bi } & 3 \text { tri } & 4 \text { quad } & 5 \text { pent } \\ 6 \text { hex } & 7 \text { sept } & 8 \text { oct } & 9 \text { enn } & 0 \text { nil }\end{array}$

The roots are combined in the order of the digits that make up the atomic number and terminated by "ium" to spell out the name. The final "n" of "enn" is deleted when occurring before "nil", and the "i" of "bi" and of "tri" is deleted when occurring before "ium".

\section{COMMENTS ON ATOMIC WEIGHTS AND ANNOTATIONS OF SELECTED ELEMENTS}

Brief descriptions of the changes to the standard atomic weights resulting from the Commission meeting in 2011 are provided below.

\subsection{Bromine}

The Commission has changed the recommended value for the standard atomic weight of bromine, $A_{\mathrm{r}}(\mathrm{Br})$, from 79.904(1) to the atomic-weight interval [79.901, 79.907] based on an evaluation of the effect of variation in isotopic abundances in normal materials upon the atomic weight of bromine. This change is intended to emphasize the fact that the atomic weight of bromine is not a constant of nature, but depends upon the source of the material (Fig. 2). The standard atomic weight was determined by combining (1) the best calibrated isotope-ratio measurement of bromine in SRM977 NaBr isotopic reference material [25,26], formerly known as NBS106 [25], (2) the relative isotope-ratio difference between SRM977 and bromide in ocean water [27], and (3) the relative isotope-ratio differences between other materials and ocean-water bromide [2,28]. Bromide in ocean water is isotopically homogeneous and serves as the international measurement standard for bromine [26], standard mean ocean bromide (SMOB). Bromine relative isotope-ratio differences, also called bromine isotope delta values, have been reported with the symbol $\delta^{81} \mathrm{Br}$ [26-28] and are defined by the relation [20]

$$
\delta^{81} \mathrm{Br}=\frac{N\left({ }^{81} \mathrm{Br}\right)_{\mathrm{P}} / N\left({ }^{79} \mathrm{Br}\right)_{\mathrm{P}}-N\left({ }^{81} \mathrm{Br}\right)_{\mathrm{SMOB}} / N\left({ }^{79} \mathrm{Br}\right)_{\mathrm{SMOB}}}{N\left({ }^{81} \mathrm{Br}\right)_{\mathrm{SMOB}} / N\left({ }^{79} \mathrm{Br}\right)_{\mathrm{SMOB}}}
$$

where $N\left({ }^{81} \mathrm{Br}\right)_{\mathrm{P}}$ and $N\left({ }^{79} \mathrm{Br}\right)_{\mathrm{P}}$ are the numbers of atoms of the two isotopes ${ }^{81} \mathrm{Br}$ and ${ }^{79} \mathrm{Br}$ in material $\mathrm{P}$ and equivalent parameters follow for bromine in SMOB. The minimum and maximum $\delta^{81} \mathrm{Br}$ values of saline waters and salt deposits (Fig. 1) are -0.8 and $+3.35 \%$ relative to SMOB [27]. The minimum and maximum $\delta^{81} \mathrm{Br}$ values of brominated organic compounds (Fig. 2) are -4.3 and $+0.2 \%$ relative to SMOB [28]. The minimum and maximum $\delta^{81} \mathrm{Br}$ values of elemental bromine (Fig. 1), calculated from isotope-ratio measurements of [25], are -0.84 and $+0.36 \%$ relative to SMOB, but measurement uncertainties were sufficiently large that isotopic abundance variations were not conclusively demonstrated [25]. The lower bound of the standard atomic weight corresponds to bromine in a brominated benzene reagent [28], and the upper bound corresponds to dissolved bromide in saline groundwater from Siberia [27]. The previous standard atomic-weight value $A_{\mathrm{r}}(\mathrm{Br})=79.904(1)$, recommended by the Commission in 1965 and published in "Atomic weights of the elements 1967" [2], was based on the measurements 


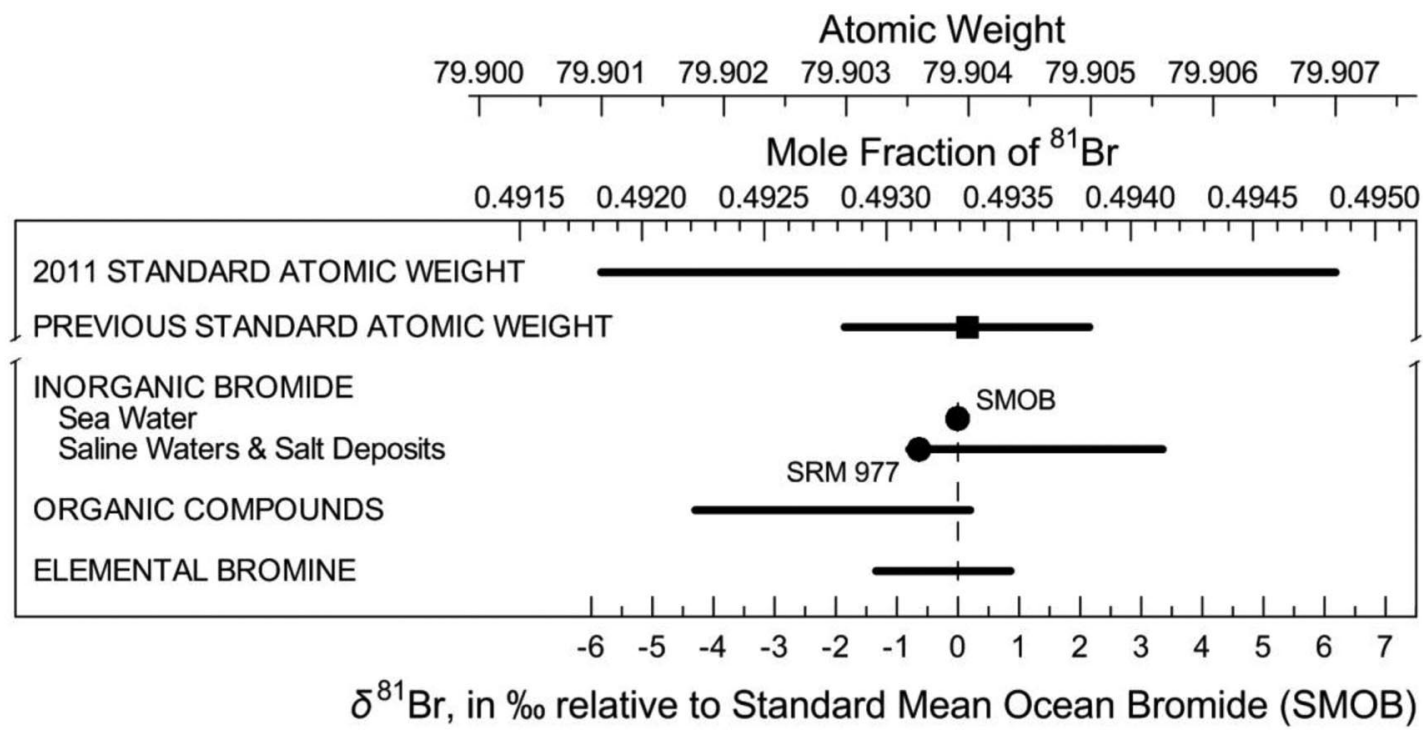

Fig. 2 Variation in isotopic composition and atomic weight of bromine in selected bromine-bearing materials. Data for inorganic bromide are from [25-27]. Data for organic compounds are from [28]. Data for elemental bromine are from [25]. Isotopic reference materials are designated by solid black circles. The previous (1965 to 2009) standard atomic weight of bromine was 79.904(1). The atomic-weight uncertainty of the best measurement of isotopic abundance [8] is approximately \pm 0.0005 , which is about four times smaller than the uncertainty of the 2009 standard atomic weight [9] and 12 times smaller than the 2011 standard-atomic-weight interval. The $\delta^{81} \mathrm{Br}$ scale and the ${ }^{81} \mathrm{Br}$ mole-fraction scale were matched using data from [25,26], and the uncertainty in placement of the atomic-weight scale and the ${ }^{81} \mathrm{Br}$ mole-fraction scale relative to the $\delta^{81} \mathrm{Br}$ scale is equivalent to $\pm 1.1 \%$.

of Catanzaro et al. [25], who found no evidence for variations in isotopic abundance in normal materials. Previous historical values of $A_{\mathrm{r}}(\mathrm{Br})$ include [22]: 1882, 79.95; 1903, 79.96; 1909, 79.92; 1925, 79.916; 1961, 79.909; and 1965, 79.904.

\subsection{Germanium}

The Commission has changed the recommended value for the standard atomic weight of germanium, $A_{\mathrm{r}}(\mathrm{Ge})$, from 72.63(1) to 72.630(8) based on an evaluation published by Yang and Meija [29]. A loglinear regression mass-bias correction using NIST SRM 994 gallium isotopic reference material enabled an improvement in the uncertainty of the atomic-weight value compared to the previous value of $A_{\mathrm{r}}(\mathrm{Ge})=72.63(1)$, assigned by the Commission in 2009 [9]. Historical values of $A_{\mathrm{r}}(\mathrm{Ge})$ include [22]: 1894, 72.3; 1897, 72.48; 1900, 72.5; 1925, 72.60; 1961, 72.59; 1969, 72.59(3); 1999, 72.64(1); 2009, 72.63(1).

\subsection{Indium}

The Commission has changed the recommended value for the standard atomic weight of indium, $A_{\mathrm{r}}(\mathrm{In})$, from 114.818(3) to $114.818(1)$ based on a partially calibrated mass-spectrometric measurement by Yang et al. [30]. The authors employed a novel approach, which enables the comparison of isotopic compositions between elements, in this case to combine the measurements of the isotopic compositions of silver and indium along with the silver isotopic composition of NIST SRM 978a. Although the comparison of isotopic compositions of elements is common in science, it usually invokes the assumption that both elements have the same behavior in mass spectrometry, an assumption that is known to be 
false. The work of Yang et al. obviates the need for such an assumption and produces an atomic-weight value of indium traceable directly to the atomic weight of silver, thus reviving a network of relationships among the isotopic compositions of various elements, which, incidentally, was one of the most salient features of the "Harvard method" for which T. W. Richards was awarded the Nobel Prize for Chemistry in 1914. Historical values of $A_{\mathrm{r}}$ (In) include [22]: 1882, 113.66; 1894, 113.7; 1897, 113.85; 1900,$114 ; 1905,115 ; 1909,114.8 ; 1934,114.76 ; 1955,114.78 ; 1969,114.82(1) ; 1991,114.818(3)$.

\subsection{Magnesium}

The Commission has changed the recommended value for the standard atomic weight of magnesium, $A_{\mathrm{r}}(\mathrm{Mg})$, from 24.3050(6) to the atomic-weight interval [24.304, 24.307] based on an evaluation of the effect of variation in isotopic abundances in normal materials upon the atomic weight of magnesium. This change is intended to emphasize the fact that the atomic weight of magnesium is not a constant of nature, but depends upon the source of the material (Fig. 3). The standard atomic weight was determined by combining (1) the best calibrated isotope-ratio measurement of magnesium in DSM3 isotopic reference material [31], a mono-elemental nitric solution of magnesium, and (2) the relative isotoperatio differences between other magnesium-bearing materials and DSM3 [32-38]. Bizzarro et al. [31] are to be congratulated for their high-precision isotopic abundance measurement of DSM3 using a double spike for correction of instrumental bias and high-resolution multicollector inductively coupled plasma-mass spectrometry. Their measurement has been accepted as a "best measurement" of isotopic abundance. The isotope ratios recommended for acceptance as a best measurement are $N\left({ }^{25} \mathrm{Mg}\right) / N\left({ }^{24} \mathrm{Mg}\right)=0.12691(11)$ and $N\left({ }^{26} \mathrm{Mg}\right) / N\left({ }^{24} \mathrm{Mg}\right)=0.13969(15)$. The isotopic abundance values to be published as a best measurement in the next Table of Isotopic Compositions of the Elements are $x\left({ }^{24} \mathrm{Mg}\right)=0.7895(1), x\left({ }^{25} \mathrm{Mg}\right)=0.10020(8)$, and $x\left({ }^{26} \mathrm{Mg}\right)=0.1103(1)$.

Magnesium relative isotope-ratio differences, also called magnesium isotope-delta values, have been reported with the symbol $\delta^{26} \mathrm{Mg}$ [31-38] and are defined by the relation [28]

$$
\delta^{26} \mathrm{Mg}=\frac{N\left({ }^{26} \mathrm{Mg}\right)_{\mathrm{P}} / N\left({ }^{24} \mathrm{Mg}\right)_{\mathrm{P}}-N\left({ }^{26} \mathrm{Mg}\right)_{\mathrm{Std}} / N\left({ }^{24} \mathrm{Mg}\right)_{\mathrm{Std}}}{N\left({ }^{26} \mathrm{Mg}\right)_{\mathrm{Std}} / N\left({ }^{24} \mathrm{Mg}\right)_{\mathrm{Std}}}
$$

where $N\left({ }^{26} \mathrm{Mg}\right)_{\mathrm{P}}$ and $N\left({ }^{24} \mathrm{Mg}\right)_{\mathrm{P}}$ are the numbers of atoms of the two isotopes ${ }^{26} \mathrm{Mg}$ and ${ }^{24} \mathrm{Mg}$ in material $\mathrm{P}$ and equivalent parameters follow for magnesium in the standard (Std). Many of the $\delta^{26} \mathrm{Mg}$ measurements reported herein were made using DSM3 as the standard. However, the Commission does not recommend DSM3 as an international measurement standard for $\delta^{26} \mathrm{Mg}$ measurements because a supply for the next 5-10 years is not readily available to laboratories worldwide.

The lower bound of the standard atomic weight corresponds to magnesium in planktonic foraminifer (Globigerinoides sacculifer) having a $\delta^{26} \mathrm{Mg}$ value of $-5.57 \%$ relative to DSM3 [32]. The upper bound of the standard atomic weight corresponds to magnesium in a specimen of olivine having a $\delta^{26} \mathrm{Mg}$ value of $+1.03 \%$ relative to DSM3 [33]. The previous standard atomic-weight value $A_{\mathrm{r}}(\mathrm{Mg})=$ 24.3050(6), recommended by the Commission in 1985 and published in "Atomic weights of the elements 1967" [2], was based on the "absolute" isotopic abundance measurements of Catanzaro et al. [39], and Catanzaro and Murphy [40] found no evidence for variations in isotopic abundance in normal materials. Previous historical values of $A_{\mathrm{r}}(\mathrm{Mg})$ include [20]: 1882, 24.01; 1894, 24.3; 1896, 24.29; 1897, 24.28; 1900, 24.3; 1903, 24.36; 1909, 24.32; 1961, 24.312; 1967, 24.305; 1969, 24.305(1); and $1985,24.3050(6)$. 


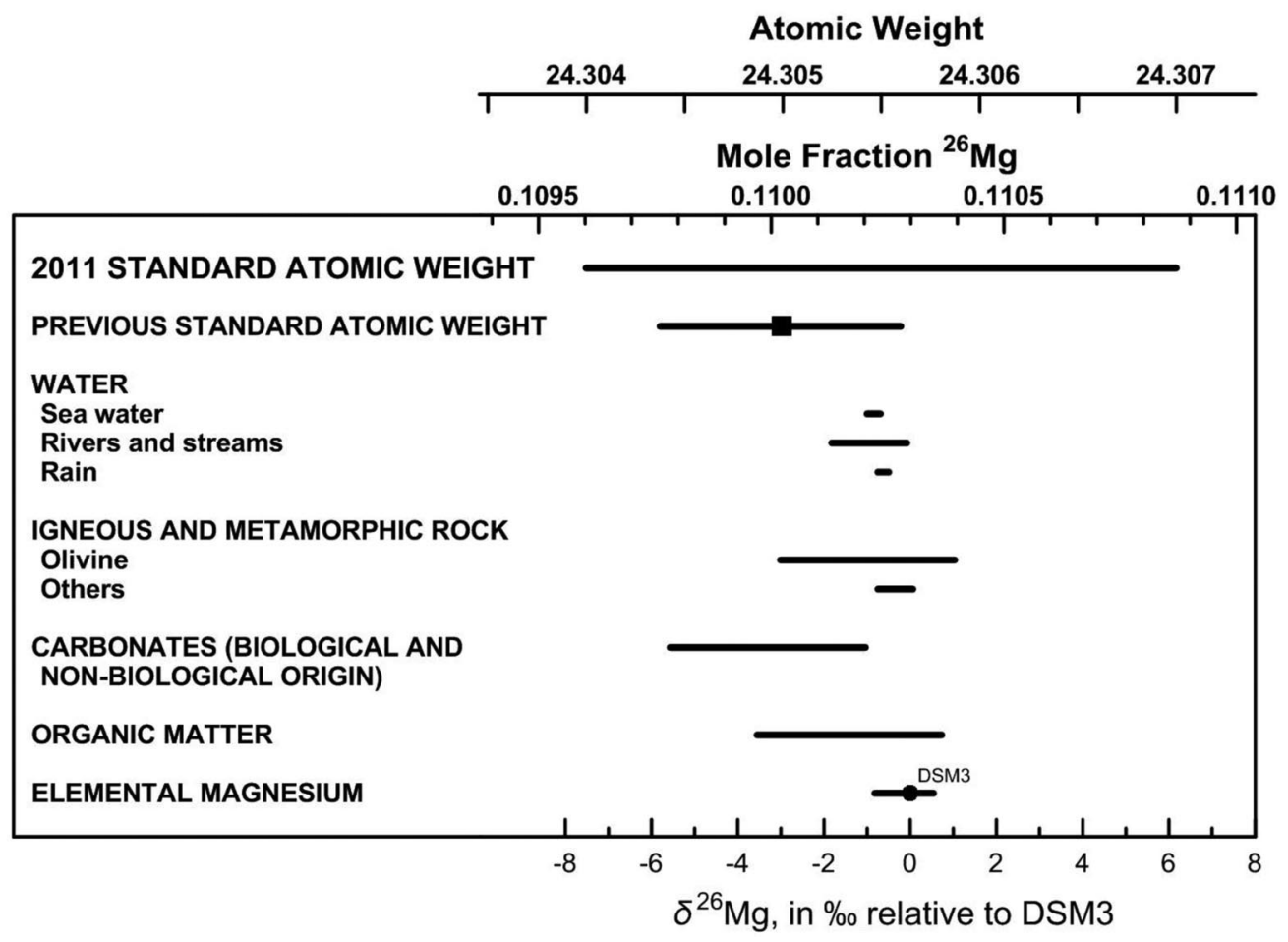

Fig. 3 Variation in isotopic composition and atomic weight of magnesium in selected magnesium-bearing materials. The $\delta^{26} \mathrm{Mg}$ measurements are expressed relative to DSM3 because many materials were measured relative to it. However, DSM3 is not recommended as the international measurement standard for the $\delta^{26} \mathrm{Mg}$ scale. Data for water are from [36-38]. Data for carbonates are from [32]. Data for igneous and metamorphic rocks are from [33,34]. Data for organic matter are from [37,38]. Data for elemental magnesium are from [35]. Isotopic reference material is designated by solid black circles. The isotopic reference material SRM 980 elemental magnesium is not shown because it is isotopically inhomogeneous [31]. The previous (1985 to 2009) standard atomic weight of magnesium was $24.3050(6)$. The atomic-weight uncertainty of the best measurement of isotopic abundance [31] is approximately \pm 0.00024 , which is about $40 \%$ that of the uncertainty of the 2009 standard atomic weight [8] and 12 times smaller than the 2011 standard-atomic-weight interval. The $\delta^{26} \mathrm{Mg}$ scale and the ${ }^{26} \mathrm{Mg}$ mole-fraction scale were matched using data from [31], and the uncertainty in placement of the atomic-weight scale and the ${ }^{26} \mathrm{Mg}$ mole-fraction scale relative to the $\delta^{26} \mathrm{Mg}$ scale is equivalent to $1.1 \%$.

\subsection{Mercury}

The Commission has changed the recommended value for the standard atomic weight of mercury, $A_{\mathrm{r}}(\mathrm{Hg})$, from 200.59(2) to 200.592(3) based on new measurements and an evaluation of the effect of the variation in isotopic abundance in normal materials by Meija and co-workers [41]. Measurements were made using a multicollector inductively coupled plasma-mass spectrometer using NIST SRM997 thallium isotopic reference material for mass-bias correction, and the investigation followed an approach similar to that used in the determination of the atomic weight of indium. The authors accounted for the difference in mass bias between thallium and mercury. The uncertainty of this new recommended value for the standard atomic weight includes the uncertainty of the standard atomic weight of thallium reported by IUPAC. Although variations in the isotopic composition of mercury have been demonstrated, those variations are too small to affect the determination of the standard atomic weight significantly. The previous standard atomic-weight value, $A_{\mathrm{r}}(\mathrm{Hg})=200.59(2)$, recommended in 1989 , was based on a determination of a nonreference material by Zadnik et al. [42]. Historical values for $A_{\mathrm{r}}(\mathrm{Hg})$ 
include [22]: 1882, 200.17; 1894, 200.0; 1912, 200.6; 1925, 200.61; 1961, 200.59; 1969, 200.59(3); 1989, 200.59(2).

\section{RELATIVE ATOMIC-MASS VALUES AND HALF-LIVES OF SELECTED RADIOACTIVE ISOTOPES}

Half-lives and relative atomic mass values have been compiled for selected radioactive isotopes and are summarized in Table 3. Long-lived radioactive isotopes of elements with a characteristic terrestrial isotopic composition that contribute to the standard atomic weight determinations are marked with the symbol $(\dagger)$ in the table. Selected radioactive isotopes for elements with no stable isotopes, with no characteristic terrestrial isotopic composition and with no standard atomic weight are presented without this symbol.

Table 3 Relative atomic masses and half-lives of selected radioactive nuclides.

$\mathrm{a}=$ year; $\mathrm{d}=$ day; $\mathrm{h}=$ hour; $\min =$ minute; $\mathrm{s}=$ second $; \mathrm{ms}=$ millisecond $\dagger$ indicates isotope contributing to the determination of a standard atomic weight.

\begin{tabular}{|c|c|c|c|c|c|c|}
\hline $\begin{array}{l}\text { Atomic } \\
\text { number }\end{array}$ & $\begin{array}{c}\text { Element } \\
\text { name }\end{array}$ & Symbol & $\begin{array}{c}\text { Mass } \\
\text { number }\end{array}$ & $\begin{array}{l}\text { Atomic } \\
\text { mass/u }\end{array}$ & Half-life & Unit \\
\hline 19 & potassium & $\mathrm{K}$ & $40^{\dagger}$ & 39.96400 & $1.248(3) \times 10^{9}$ & $\mathrm{a}$ \\
\hline 20 & calcium & $\mathrm{Ca}$ & $48^{\dagger}$ & 47.9525 & $4.4(6) \times 10^{19}$ & $\mathrm{a}$ \\
\hline 23 & vanadium & $\mathrm{V}$ & $50^{\dagger}$ & 49.94716 & $1.4(4) \times 10^{17}$ & $\mathrm{a}$ \\
\hline 32 & germanium & $\mathrm{Ge}$ & $76^{\dagger}$ & 75.9214 & $1.5(1) \times 10^{21}$ & $\mathrm{a}$ \\
\hline 34 & selenium & $\mathrm{Se}$ & $82^{\dagger}$ & 81.9167 & $0.92(7) \times 10^{20}$ & $\mathrm{a}$ \\
\hline 37 & rubidium & $\mathrm{Rb}$ & $87^{\dagger}$ & 86.909180 & $4.97(1) \times 10^{10}$ & $\mathrm{a}$ \\
\hline 40 & zirconium & $\mathrm{Zr}$ & $96^{\dagger}$ & 95.9083 & $2.3(2) \times 10^{19}$ & $\mathrm{a}$ \\
\hline 42 & molybdenum & Mo & $100^{\dagger}$ & 99.9075 & $7(1) \times 10^{18}$ & $\mathrm{a}$ \\
\hline \multirow[t]{3}{*}{43} & technetium & $\mathrm{Tc}$ & 97 & 96.9064 & $4.2(16) \times 10^{6}$ & $\mathrm{a}$ \\
\hline & & & 98 & 97.9072 & $6.1(10) \times 10^{5}$ & $\mathrm{a}$ \\
\hline & & & 99 & 98.9063 & $2.1(3) \times 10^{5}$ & $\mathrm{a}$ \\
\hline \multirow[t]{2}{*}{48} & cadmium & $\mathrm{Cd}$ & $113^{\dagger}$ & 112.9044 & $8.04(5) \times 10^{15}$ & $\mathrm{a}$ \\
\hline & & & $116^{\dagger}$ & 115.9048 & $3.0(2) \times 10^{19}$ & $\mathrm{a}$ \\
\hline 49 & indium & In & $115^{\dagger}$ & 114.9039 & $4.4(3) \times 10^{14}$ & $\mathrm{a}$ \\
\hline \multirow[t]{2}{*}{52} & tellurium & $\mathrm{Te}$ & $128^{\dagger}$ & 127.9045 & $2.5(3) \times 10^{24}$ & $\mathrm{a}$ \\
\hline & & & $130^{\dagger}$ & 129.9062 & $7(1) \times 10^{20}$ & a \\
\hline 54 & xenon & $\mathrm{Xe}$ & $136^{\dagger}$ & 135.9072 & $2.3(2) \times 10^{21}$ & a \\
\hline 56 & barium & $\mathrm{Ba}$ & $130^{\dagger}$ & 129.9063 & $2.2(5) \times 10^{21}$ & $\mathrm{a}$ \\
\hline 57 & lanthanum & $\mathrm{La}$ & $138^{\dagger}$ & 137.9071 & $1.06(4) \times 10^{11}$ & a \\
\hline \multirow[t]{2}{*}{60} & neodymium & $\mathrm{Nd}$ & $144^{\dagger}$ & 143.9101 & $2.3(2) \times 10^{15}$ & $\mathrm{a}$ \\
\hline & & & $150^{\dagger}$ & 149.9209 & $1.33(5) \times 10^{20}$ & a \\
\hline \multirow[t]{3}{*}{61} & promethium & $\mathrm{Pm}$ & 145 & 144.9127 & $17.7(4)$ & a \\
\hline & & & 146 & 145.9147 & $5.53(5)$ & a \\
\hline & & & 147 & 146.9151 & $2.623(3)$ & $\mathrm{a}$ \\
\hline \multirow[t]{2}{*}{62} & samarium & $\mathrm{Sm}$ & $147^{\dagger}$ & 146.9149 & $1.07(1) \times 10^{11}$ & $\mathrm{a}$ \\
\hline & & & $148^{\dagger}$ & 147.9148 & $7(3) \times 10^{15}$ & $\mathrm{a}$ \\
\hline 71 & lutetium & $\mathrm{Lu}$ & $176^{\dagger}$ & 175.9427 & $3.73(3) \times 10^{10}$ & $\mathrm{a}$ \\
\hline 72 & hafnium & Hf & $174^{\dagger}$ & 173.94 & $2.0(4) \times 10^{15}$ & $\mathrm{a}$ \\
\hline 74 & tungsten & $\mathrm{W}$ & $180^{\dagger}$ & 179.9467 & $1.8(2) \times 10^{18}$ & a \\
\hline 75 & rhenium & $\mathrm{Re}$ & $187^{\dagger}$ & 186.95575 & $4.16(1) \times 10^{10}$ & a \\
\hline 76 & osmium & Os & $186^{\dagger}$ & 185.95384 & $2(1) \times 10^{15}$ & $\mathrm{a}$ \\
\hline 78 & platinum & $\mathrm{Pt}$ & $190^{\dagger}$ & 189.9599 & $4.5(1) \times 10^{11}$ & $\mathrm{a}$ \\
\hline
\end{tabular}


Table 3 (Continued).

\begin{tabular}{|c|c|c|c|c|c|c|}
\hline $\begin{array}{l}\text { Atomic } \\
\text { number }\end{array}$ & $\begin{array}{c}\text { Element } \\
\text { name }\end{array}$ & Symbol & $\begin{array}{c}\text { Mass } \\
\text { number }\end{array}$ & $\begin{array}{c}\text { Atomic } \\
\text { mass }\end{array}$ & Half-life & Unit \\
\hline 83 & bismuth & $\mathrm{Bi}$ & $209^{\dagger}$ & 208.9804 & $2.0(1) \times 10^{19}$ & $\mathrm{a}$ \\
\hline \multirow[t]{3}{*}{84} & polonium & Po & 208 & 207.9812 & $2.90(1)$ & $\mathrm{a}$ \\
\hline & & & 209 & 208.9824 & $1.28(7) \times 10^{2}$ & $\mathrm{a}$ \\
\hline & & & 210 & 209.9829 & $138.4(1)$ & $\mathrm{d}$ \\
\hline \multirow[t]{2}{*}{85} & astatine & At & 210 & 209.9871 & $8.1(4)$ & $\mathrm{h}$ \\
\hline & & & 211 & 210.9875 & $7.21(1)$ & $\mathrm{h}$ \\
\hline \multirow[t]{3}{*}{86} & radon & $\mathrm{Rn}$ & 210 & 209.9897 & $2.4(1)$ & $\mathrm{h}$ \\
\hline & & & 211 & 210.9906 & $14.6(2)$ & $\mathrm{h}$ \\
\hline & & & 222 & 222.0176 & $3.823(4)$ & $\mathrm{d}$ \\
\hline \multirow[t]{3}{*}{87} & francium & $\mathrm{Fr}$ & 212 & 211.9962 & $20.0(6)$ & $\min$ \\
\hline & & & 222 & 222.0176 & $14.2(3)$ & $\min$ \\
\hline & & & 223 & 223.0197 & $22.0(1)$ & $\min$ \\
\hline \multirow[t]{2}{*}{88} & radium & $\mathrm{Ra}$ & 226 & 226.0254 & $1.599(4) \times 10^{3}$ & $\mathrm{a}$ \\
\hline & & & 228 & 228.0311 & $5.76(3)$ & $\mathrm{a}$ \\
\hline \multirow[t]{2}{*}{89} & actinium & Ac & 225 & 225.0232 & $10.0(1)$ & $\mathrm{d}$ \\
\hline & & & 227 & 227.0278 & $21.77(2)$ & $\mathrm{a}$ \\
\hline \multirow[t]{2}{*}{90} & thorium & $\mathrm{Th}$ & 230 & 230.0331 & $7.56(3) \times 10^{4}$ & $\mathrm{a}$ \\
\hline & & & $232^{\dagger}$ & 232.0381 & $1.40(1) \times 10^{10}$ & $\mathrm{a}$ \\
\hline \multirow[t]{2}{*}{91} & protactinium & $\mathrm{Pa}$ & $231^{\dagger}$ & 231.0359 & $3.25(1) \times 10^{4}$ & $\mathrm{a}$ \\
\hline & & & 233 & 233.04025 & $27.0(1)$ & $\mathrm{d}$ \\
\hline \multirow[t]{5}{*}{92} & uranium & $\mathrm{U}$ & 233 & 233.0396 & $1.590(3) \times 10^{5}$ & $\mathrm{a}$ \\
\hline & & & $234^{\dagger}$ & 234.041 & $2.454(2) \times 10^{5}$ & $\mathrm{a}$ \\
\hline & & & $235^{\dagger}$ & 235.0439 & $7.034(2) \times 10^{8}$ & $\mathrm{a}$ \\
\hline & & & 236 & 236.0456 & $2.342(4) \times 10^{7}$ & $\mathrm{a}$ \\
\hline & & & $238^{\dagger}$ & 238.0508 & $4.468(5) \times 10^{9}$ & $\mathrm{a}$ \\
\hline \multirow[t]{2}{*}{93} & neptunium & $\mathrm{Np}$ & 236 & 236.0466 & $1.55(6) \times 10^{5}$ & $\mathrm{a}$ \\
\hline & & & 237 & 237.0482 & $2.14(1) \times 10^{6}$ & $\mathrm{a}$ \\
\hline \multirow[t]{6}{*}{94} & plutonium & $\mathrm{Pu}$ & 238 & 238.0496 & $87.7(1)$ & $\mathrm{a}$ \\
\hline & & & 239 & 239.0522 & $2.410(3) \times 10^{4}$ & $\mathrm{a}$ \\
\hline & & & 240 & 240.0538 & $6.56(1) \times 10^{3}$ & $\mathrm{a}$ \\
\hline & & & 241 & 241.0569 & $14.33(3)$ & $\mathrm{a}$ \\
\hline & & & 242 & 242.0587 & $3.75(2) \times 10^{5}$ & $\mathrm{a}$ \\
\hline & & & 244 & 244.0642 & $8.12(3) \times 10^{7}$ & $\mathrm{a}$ \\
\hline \multirow[t]{2}{*}{95} & americium & Am & 241 & 241.0568 & $432.7(6)$ & $\mathrm{a}$ \\
\hline & & & 243 & 243.0614 & $7.37(2) \times 10^{3}$ & $\mathrm{a}$ \\
\hline \multirow[t]{6}{*}{96} & curium & $\mathrm{Cm}$ & 243 & 243.0614 & $29.1(1)$ & $\mathrm{a}$ \\
\hline & & & 244 & 244.0628 & $18.3(1)$ & $\mathrm{a}$ \\
\hline & & & 245 & 245.0655 & $8.48(6) \times 10^{3}$ & $\mathrm{a}$ \\
\hline & & & 246 & 246.0672 & $4.73(3) \times 10^{3}$ & $\mathrm{a}$ \\
\hline & & & 247 & 247.0704 & $1.56(5) \times 10^{7}$ & $\mathrm{a}$ \\
\hline & & & 248 & 248.0723 & $3.48(6) \times 10^{5}$ & $\mathrm{a}$ \\
\hline \multirow[t]{2}{*}{97} & berkelium & $\mathrm{Bk}$ & 247 & 247.0703 & $1.4(3) \times 10^{3}$ & $\mathrm{a}$ \\
\hline & & & 249 & 249.075 & $3.20(3) \times 10^{2}$ & $\mathrm{~d}$ \\
\hline \multirow[t]{4}{*}{98} & californium & $\mathrm{Cf}$ & 249 & 249.0749 & $351(2)$ & $\mathrm{a}$ \\
\hline & & & 250 & 250.0764 & $13.1(1)$ & $\mathrm{a}$ \\
\hline & & & 251 & 251.0796 & $9.0(5) \times 10^{2}$ & $\mathrm{a}$ \\
\hline & & & 252 & 252.0816 & $2.65(1)$ & $\mathrm{a}$ \\
\hline
\end{tabular}

(continues on next page) 
Table 3 (Continued).

\begin{tabular}{|c|c|c|c|c|c|c|}
\hline $\begin{array}{l}\text { Atomic } \\
\text { number }\end{array}$ & $\begin{array}{l}\text { Element } \\
\text { name }\end{array}$ & Symbol & $\begin{array}{c}\text { Mass } \\
\text { number }\end{array}$ & $\begin{array}{l}\text { Atomic } \\
\text { mass }\end{array}$ & Half-life & Unit \\
\hline \multirow[t]{2}{*}{99} & einsteinium & Es & 252 & 252.083 & $472(2)$ & d \\
\hline & & & 254 & 254.088 & 276(1) & d \\
\hline \multirow[t]{2}{*}{100} & fermium & $\mathrm{Fm}$ & 253 & 253.0852 & $3.0(1)$ & d \\
\hline & & & 257 & 257.0951 & $100.5(2)$ & d \\
\hline \multirow[t]{2}{*}{101} & mendelevium & Md & 258 & 258.0984 & $51.5(3)$ & $\mathrm{d}$ \\
\hline & & & 260 & 260.1 & $27.8(3)$ & d \\
\hline \multirow[t]{2}{*}{102} & nobelium & No & 255 & 255.0932 & $3.1(2)$ & $\min$ \\
\hline & & & 259 & 259.101 & $58(5)$ & $\min$ \\
\hline \multirow[t]{3}{*}{103} & lawrencium & $\mathrm{Lr}$ & 251 & 251.09 & $\sim 39$ & $\min$ \\
\hline & & & 261 & 261.11 & $\sim 40$ & $\min$ \\
\hline & & & 262 & 262.11 & $3.6(3)$ & $\mathrm{h}$ \\
\hline \multirow[t]{2}{*}{104} & rutherfordium & $\mathrm{Rf}$ & 265 & 265.12 & $\sim 11$ & $\min$ \\
\hline & & & 267 & 267.12 & $\sim 1$ & $\mathrm{~h}$ \\
\hline \multirow[t]{2}{*}{105} & dubnium & $\mathrm{Db}$ & 268 & 268.13 & $26(6)$ & $\mathrm{h}$ \\
\hline & & & 270 & 270.13 & $\sim 0.9$ & $\mathrm{~d}$ \\
\hline \multirow[t]{2}{*}{106} & seaborgium & $\mathrm{Sg}$ & 267 & 267.12 & $\sim 1.3$ & $\min$ \\
\hline & & & 271 & 271.13 & $\sim 2$ & $\min$ \\
\hline \multirow[t]{2}{*}{107} & bohrium & $\mathrm{Bh}$ & 270 & 270.13 & $\sim 1$ & $\min$ \\
\hline & & & 274 & 274.14 & $\sim 0.9$ & $\min$ \\
\hline \multirow[t]{2}{*}{108} & hassium & Hs & 270 & 270.13 & 23 & s \\
\hline & & & 277 & 277.15 & $\sim 0.8$ & $\min$ \\
\hline \multirow[t]{2}{*}{109} & meitnerium & Mt & 276 & 276.15 & $\sim 6$ & s \\
\hline & & & 278 & 278.16 & $\sim 5$ & s \\
\hline \multirow[t]{2}{*}{110} & darmstadtium & Ds & 280 & 280.16 & $\sim 7.6$ & s \\
\hline & & & 281 & 281.17 & $20(8)$ & s \\
\hline \multirow[t]{2}{*}{111} & roentgenium & $\mathrm{Rg}$ & 281 & 281.17 & $22(8)$ & $\mathrm{s}$ \\
\hline & & & 282 & 282.17 & $\sim 0.7$ & $\min$ \\
\hline \multirow[t]{2}{*}{112} & copernicium & $\mathrm{Cn}$ & 283 & 283.17 & $4(1)$ & $\mathrm{s}$ \\
\hline & & & 285 & 285.18 & 0.8 & $\min$ \\
\hline \multirow[t]{2}{*}{113} & ununtritium & Uut & 285 & 285.18 & $6(2)$ & $\mathrm{s}$ \\
\hline & & & 286 & 286.18 & $\sim 0.9$ & $\mathrm{~s}$ \\
\hline \multirow[t]{2}{*}{114} & flerovium & $\mathrm{Fl}$ & 288 & 288.19 & $0.8(2)$ & s \\
\hline & & & 289 & 289.19 & $3(1)$ & s \\
\hline \multirow[t]{3}{*}{115} & ununpentium & Uup & 288 & 288.19 & $0.17(4)$ & s \\
\hline & & & 289 & 289.19 & $0.4(2)$ & $\mathrm{s}$ \\
\hline & & & 290 & 290.2 & $\sim 0.2$ & s \\
\hline \multirow[t]{3}{*}{116} & livermorium & $\mathrm{Lv}$ & 291 & 291.2 & $\sim 0.02$ & s \\
\hline & & & 292 & 292.2 & $0.02(1)$ & s \\
\hline & & & 293 & 293.2 & $0.08(7)$ & $\mathrm{s}$ \\
\hline \multirow[t]{2}{*}{117} & ununseptium & Uus & 293 & 293.21 & $0.03(1)$ & s \\
\hline & & & 294 & 294.21 & $\sim 0.05$ & $\mathrm{~s}$ \\
\hline 118 & ununoctium & Uuo & 294 & 294.21 & $0.7(6)$ & $\mathrm{ms}$ \\
\hline
\end{tabular}

Names of elements with atomic number 113, 115, 117, and 118 are provisional; they have been reported in the peer-reviewed scientific literature, but they have not yet been named by IUPAC. Listing of particular isotopes for these elements does not imply any priority of the discovery of those elements on the part of IUPAC or the Commission on Isotopic Abundances and Atomic Weights. There is no general agreement on which of the various isotopes of radioactive elements is, or is likely to be judged, 
"important". Various criteria such as "longest half-life", "production in quantity", and "used commercially" have been applied in the past.

The Commission has no official responsibility for the dissemination of atomic masses or radioactive half-lives. The information contained in this table will enable the user to calculate atomic weights of radioactive materials with a variety of isotopic compositions. The atomic mass values listed are considered to be accurate to \pm 1 in the last digit quoted and are taken from the 2012 atomic mass table [43]. The half-life values quoted can be considered accurate at the one standard deviation level and are taken from the "Table of the Isotopes" of the CRC Handbook of Chemistry and Physics and its updates [44].

\section{ABRIDGED TABLES OF STANDARD ATOMIC WEIGHTS}

The detail and number of significant digits reported in the full Table of Standard Atomic Weights (Tables 1 and 2) exceeds the needs and the interests of many users. Tables abridged to four or five significant digits are published with the expectation that subsequent changes to the abridged values will be minimal. Standard atomic weights abridged to four and five significant digits are presented in Tables 4 and 5, respectively. Users seeking an atomic-weight value that is not an interval, such as for trade and commerce, can refer to a conventional atomic-weight value in Section 6.

Table 4 Standard atomic weights 2011 abridged to four significant digits. [Scaled to $A_{\mathrm{r}}\left({ }^{12} \mathrm{C}\right)=12$, where ${ }^{12} \mathrm{C}$ is a neutral atom in its nuclear and electronic ground state.]

The atomic weights of many elements are not invariant, but depend on the origin and treatment of the material. The standard values of $A_{\mathrm{r}}(\mathrm{E})$ and the uncertainties (in parentheses, following the last significant digit to which they are attributed) apply to elements from normal materials. The last significant figure of each tabulated value is considered reliable to \pm 1 except when a larger single digit uncertainty is inserted in parentheses following the atomic weight. For 12 of these elements, the standard atomic weight is given as an atomicweight interval with the symbol $[a, b]$ to denote the set of atomic-weight values in normal materials; thus, $a \leq A_{\mathrm{r}}(\mathrm{E}) \leq b$. The symbols $a$ and $b$ denote the lower and upper bounds of the interval $[a, b]$, respectively. Names of elements with atomic number $113,115,117$, and 118 are provisional; they have been reported in the peer-reviewed, scientific literature, but they have not yet been named by IUPAC.

\begin{tabular}{rllc}
\hline Atomic number & \multicolumn{1}{c}{ Element name } & Symbol & Atomic weight \\
\hline 1 & hydrogen & $\mathrm{H}$ & {$[1.007,1.009]$} \\
2 & helium & $\mathrm{He}$ & 4.003 \\
3 & lithium & $\mathrm{Li}$ & {$[6.938,6.997]$} \\
4 & beryllium & $\mathrm{Be}$ & 9.012 \\
5 & boron & $\mathrm{B}$ & {$[10.80,10.83]$} \\
6 & carbon & $\mathrm{C}$ & {$[12.00,12.02]$} \\
7 & nitrogen & $\mathrm{N}$ & {$[14.00,14.01]$} \\
8 & oxygen & $\mathrm{O}$ & {$[15.99,16.00]$} \\
9 & fluorine & $\mathrm{F}$ & 19.00 \\
10 & neon & $\mathrm{Ne}$ & 20.18 \\
11 & sodium & $\mathrm{Na}$ & 22.99 \\
12 & magnesium & $\mathrm{Mg}$ & {$[24.30,24.31]$} \\
13 & aluminium (aluminum) & $\mathrm{Al}$ & 26.98 \\
14 & silicon & $\mathrm{Si}$ & {$[28.08,28.09]$}
\end{tabular}

(continues on next page) 
Table 4 (Continued).

\begin{tabular}{|c|c|c|c|}
\hline Atomic number & Element name & Symbol & Atomic weight \\
\hline 15 & phosphorus & $\mathrm{P}$ & 30.97 \\
\hline 16 & sulfur & $\mathrm{S}$ & {$[32.05,32.08]$} \\
\hline 17 & chlorine & $\mathrm{Cl}$ & {$[35.44,35.46]$} \\
\hline 18 & argon & $\mathrm{Ar}$ & 39.95 \\
\hline 19 & potassium & $\mathrm{K}$ & 39.10 \\
\hline 20 & calcium & $\mathrm{Ca}$ & $40.08^{\#}$ \\
\hline 21 & scandium & $\mathrm{Sc}$ & 44.96 \\
\hline 22 & titanium & $\mathrm{Ti}$ & 47.87 \\
\hline 23 & vanadium & $\mathrm{V}$ & 50.94 \\
\hline 24 & chromium & $\mathrm{Cr}$ & 52.00 \\
\hline 25 & manganese & Mn & 54.94 \\
\hline 26 & iron & $\mathrm{Fe}$ & 55.85 \\
\hline 27 & cobalt & $\mathrm{Co}$ & 58.93 \\
\hline 28 & nickel & $\mathrm{Ni}$ & 58.69 \\
\hline 29 & copper & $\mathrm{Cu}$ & 63.55 \\
\hline 30 & zinc & $\mathrm{Zn}$ & $65.38(2)$ \\
\hline 31 & gallium & $\mathrm{Ga}$ & 69.72 \\
\hline 32 & germanium & $\mathrm{Ge}$ & 72.63 \\
\hline 33 & arsenic & As & 74.92 \\
\hline 34 & selenium & $\mathrm{Se}$ & $78.96(3)$ \\
\hline 35 & bromine & $\mathrm{Br}$ & {$[79.90,79.91]$} \\
\hline 36 & krypton & $\mathrm{Kr}$ & $83.80^{\#}$ \\
\hline 37 & rubidium & $\mathrm{Rb}$ & $85.47^{\#}$ \\
\hline 38 & strontium & $\mathrm{Sr}$ & $87.62^{\#}$ \\
\hline 39 & yttrium & $\mathrm{Y}$ & 88.91 \\
\hline 40 & zirconium & $\mathrm{Zr}$ & $91.22^{\#}$ \\
\hline 41 & niobium & $\mathrm{Nb}$ & 92.91 \\
\hline 42 & molybdenum & Mo & $95.96(2)^{\#}$ \\
\hline 43 & technetium* & $\mathrm{Tc}$ & \\
\hline 44 & ruthenium & $\mathrm{Ru}$ & $101.1^{\#}$ \\
\hline 45 & rhodium & $\mathrm{Rh}$ & 102.9 \\
\hline 46 & palladium & $\mathrm{Pd}$ & $106.4^{\#}$ \\
\hline 47 & silver & $\mathrm{Ag}$ & $107.9^{\#}$ \\
\hline 48 & cadmium & $\mathrm{Cd}$ & $112.4^{\#}$ \\
\hline 49 & indium & In & 114.8 \\
\hline 50 & $\operatorname{tin}$ & $\mathrm{Sn}$ & $118.7^{\#}$ \\
\hline 51 & antimony & $\mathrm{Sb}$ & $121.8^{\#}$ \\
\hline 52 & tellurium & $\mathrm{Te}$ & $127.6^{\#}$ \\
\hline 53 & iodine & I & 126.9 \\
\hline 54 & xenon & $\mathrm{Xe}$ & $131.3^{\#}$ \\
\hline 55 & caesium (cesium) & Cs & 132.9 \\
\hline 56 & barium & $\mathrm{Ba}$ & 137.3 \\
\hline 57 & lanthanum & $\mathrm{La}$ & 138.9 \\
\hline 58 & cerium & $\mathrm{Ce}$ & $140.1^{\#}$ \\
\hline 59 & praseodymium & $\operatorname{Pr}$ & 140.9 \\
\hline 60 & neodymium & $\mathrm{Nd}$ & $144.2^{\#}$ \\
\hline 61 & promethium* & $\mathrm{Pm}$ & \\
\hline 62 & samarium & $\mathrm{Sm}$ & $150.4^{\#}$ \\
\hline 63 & europium & $\mathrm{Eu}$ & $152.0^{\#}$ \\
\hline
\end{tabular}

(continues on next page) 
Table 4 (Continued).

\begin{tabular}{|c|c|c|c|}
\hline Atomic number & Element name & Symbol & Atomic weight \\
\hline 64 & gadolinium & $\mathrm{Gd}$ & $157.3^{\#}$ \\
\hline 65 & terbium & $\mathrm{Tb}$ & 158.9 \\
\hline 66 & dysprosium & Dy & $162.5^{\#}$ \\
\hline 67 & holmium & Но & 164.9 \\
\hline 68 & erbium & $\mathrm{Er}$ & $167.3^{\#}$ \\
\hline 69 & thulium & $\mathrm{Tm}$ & 168.9 \\
\hline 70 & ytterbium & $\mathrm{Yb}$ & $173.1^{\#}$ \\
\hline 71 & lutetium & $\mathrm{Lu}$ & 175.0 \\
\hline 72 & hafnium & Hf & 178.5 \\
\hline 73 & tantalum & $\mathrm{Ta}$ & 180.9 \\
\hline 74 & tungsten & $\mathrm{W}$ & 183.8 \\
\hline 75 & rhenium & $\mathrm{Re}$ & 186.2 \\
\hline 76 & osmium & Os & 190.2 \\
\hline 77 & iridium & $\mathrm{Ir}$ & 192.2 \\
\hline 78 & platinum & $\mathrm{Pt}$ & 195.1 \\
\hline 79 & gold & $\mathrm{Au}$ & 197.0 \\
\hline 80 & mercury & $\mathrm{Hg}$ & 200.6 \\
\hline 81 & thallium & $\mathrm{Tl}$ & {$[204.3,204.4]$} \\
\hline 82 & lead & $\mathrm{Pb}$ & 207.2 \\
\hline 83 & bismuth* & $\mathrm{Bi}$ & 209.0 \\
\hline 84 & polonium* & Po & \\
\hline 85 & astatine* & At & \\
\hline 86 & radon* & $\mathrm{Rn}$ & \\
\hline 87 & francium* & $\mathrm{Fr}$ & \\
\hline 88 & radium* & $\mathrm{Ra}$ & \\
\hline 89 & actinium* & Ac & \\
\hline 90 & thorium* & $\mathrm{Th}$ & 232.0 \\
\hline 91 & protactinium* & $\mathrm{Pa}$ & 231.0 \\
\hline 92 & uranium* & $\mathrm{U}$ & $238.0^{\#}$ \\
\hline 93 & neptunium* & $\mathrm{Np}$ & \\
\hline 94 & plutonium* & $\mathrm{Pu}$ & \\
\hline 95 & americium* & Am & \\
\hline 96 & curium* & $\mathrm{Cm}$ & \\
\hline 97 & berkelium* & $\mathrm{Bk}$ & \\
\hline 98 & californium* & $\mathrm{Cf}$ & \\
\hline 99 & einsteinium* & Es & \\
\hline 100 & fermium* & $\mathrm{Fm}$ & \\
\hline 101 & mendelevium* & Md & \\
\hline 102 & nobelium* & No & \\
\hline 103 & lawrencium* & $\mathrm{Lr}$ & \\
\hline 104 & rutherfordium* & $\mathrm{Rf}$ & \\
\hline 105 & dubnium* & $\mathrm{Db}$ & \\
\hline 106 & seaborgium* & $\mathrm{Sg}$ & \\
\hline 107 & bohrium* & $\mathrm{Bh}$ & \\
\hline 108 & hassium* & Hs & \\
\hline 109 & meitnerium* & Mt & \\
\hline 110 & darmstadtium* & Ds & \\
\hline 111 & roentgenium* & $\mathrm{Rg}$ & \\
\hline 112 & copernicium $*$ & $\mathrm{Cn}$ & \\
\hline
\end{tabular}


Table 4 (Continued).

\begin{tabular}{llll}
\hline Atomic number & \multicolumn{1}{c}{ Element name } & Symbol & Atomic weight \\
\hline 113 & ununtrium* & Uut & \\
114 & flerovium & $\mathrm{Fl}$ & \\
115 & ununpentium* & Uup & \\
116 & livermorium* & Lv & \\
117 & ununseptium* & Uus \\
118 & ununoctium* & Uuo \\
\hline
\end{tabular}

*Element has no stable isotopes. One or more representative isotopes are given in Table 3 with the appropriate relative atomic mass and half-life. However, four such elements ( $\mathrm{Bi}, \mathrm{Th}, \mathrm{Pa}$, and $\mathrm{U}$ ) do have a characteristic terrestrial isotopic composition, and for these elements, standard atomic weights are tabulated.

\#Values may differ from the atomic weights of the relevant elements in some normal materials because of a variation in the isotopic abundances of the element's stable isotopes.

Table 5 Standard atomic weights 2011 abridged to five significant digits.

[Scaled to $A_{\mathrm{r}}\left({ }^{12} \mathrm{C}\right)=12$, where ${ }^{12} \mathrm{C}$ is a neutral atom in its nuclear and electronic ground state.]

The atomic weights of many elements are not invariant, but depend on the origin and treatment of the material. The standard values of $A_{\mathrm{r}}(\mathrm{E})$ and the uncertainties (in parentheses, following the last significant digit to which they are attributed) apply to elements from normal materials. The last significant figure of each tabulated value is considered reliable to \pm 1 except when a larger single digit uncertainty is inserted in parentheses following the atomic weight. For 12 of these elements, the standard atomic weight is given as an atomicweight interval with the symbol $[a, b]$ to denote the set of atomic-weight values in normal materials; thus, $a \leq A_{\mathrm{r}}(\mathrm{E}) \leq b$. The symbols $a$ and $b$ denote the lower and upper bounds of the interval $[a, b]$, respectively. Names of elements with atomic number $113,115,117$, and 118 are provisional; they have been reported in the peer-reviewed, scientific literature, but they have not yet been named by IUPAC.

\begin{tabular}{rllcc}
\hline \multicolumn{5}{c}{ Order of atomic number } \\
\hline Atomic number & \multicolumn{1}{c}{ Element name } & Symbol & Atomic weight & Footnotes \\
\hline 1 & hydrogen & $\mathrm{H}$ & {$[1.0078,1.0082]$} & $\mathrm{m}$ \\
2 & helium & $\mathrm{He}$ & 4.0026 & \\
3 & lithium & $\mathrm{Li}$ & {$[6.938,6.997]$} & $\mathrm{m}$ \\
4 & beryllium & $\mathrm{Be}$ & 9.0122 & \\
5 & boron & $\mathrm{B}$ & {$[10.806,10.821]$} & $\mathrm{m}$ \\
6 & carbon & $\mathrm{C}$ & {$[12.009,12.012]$} & \\
7 & nitrogen & $\mathrm{N}$ & {$[14.006,14.008]$} & \\
8 & oxygen & $\mathrm{O}$ & {$[15.999,16.000]$} & \\
9 & fluorine & $\mathrm{F}$ & 18.998 & $\mathrm{~m}$ \\
10 & neon & $\mathrm{Ne}$ & 20.180 & \\
11 & sodium & $\mathrm{Na}$ & 22.990 & \\
12 & magnesium & $\mathrm{Mg}$ & {$[24.304,24.307]$} & \\
13 & aluminium (aluminum) & $\mathrm{Al}$ & 26.982 & \\
14 & silicon & $\mathrm{Si}$ & {$[28.084,28.086]$} & \\
15 & phosphorus & $\mathrm{P}$ & 30.974 & \\
16 & sulfur & $\mathrm{S}$ & {$[32.059,32.076]$} & \\
17 & chlorine & $\mathrm{Cl}$ & {$[35.446,35.457]$} & $\mathrm{m}$
\end{tabular}

(continues on next page) 
Table 5 (Continued).

\begin{tabular}{|c|c|c|c|c|c|}
\hline \multicolumn{6}{|c|}{ Order of atomic number } \\
\hline Atomic number & Element name & Symbol & Atomic weight & Footn & hotes \\
\hline 18 & argon & $\mathrm{Ar}$ & 39.948 & $\mathrm{~g}$ & $\mathrm{r}$ \\
\hline 19 & potassium & $\mathrm{K}$ & 39.098 & $\mathrm{~g}$ & \\
\hline 20 & calcium & $\mathrm{Ca}$ & $40.078(4)$ & g & \\
\hline 21 & scandium & $\mathrm{Sc}$ & 44.956 & & \\
\hline 22 & titanium & $\mathrm{Ti}$ & 47.867 & & \\
\hline 23 & vanadium & $\mathrm{V}$ & 50.942 & & \\
\hline 24 & chromium & $\mathrm{Cr}$ & 51.996 & & \\
\hline 25 & manganese & $\mathrm{Mn}$ & 54.938 & & \\
\hline 26 & iron & $\mathrm{Fe}$ & $55.845(2)$ & & \\
\hline 27 & cobalt & $\mathrm{Co}$ & 58.933 & & \\
\hline 28 & nickel & $\mathrm{Ni}$ & 58.693 & & $\mathrm{r}$ \\
\hline 29 & copper & $\mathrm{Cu}$ & $63.546(3)$ & & $\mathrm{r}$ \\
\hline 30 & zinc & $\mathrm{Zn}$ & $65.38(2)$ & & $\mathrm{r}$ \\
\hline 31 & gallium & $\mathrm{Ga}$ & 69.723 & & \\
\hline 32 & germanium & $\mathrm{Ge}$ & 72.630 & & \\
\hline 33 & arsenic & As & 74.922 & & \\
\hline 34 & selenium & $\mathrm{Se}$ & $78.96(3)$ & & $\mathrm{r}$ \\
\hline 35 & bromine & $\mathrm{Br}$ & {$[79.901,79.907]$} & & \\
\hline 36 & krypton & $\mathrm{Kr}$ & $83.798(2)$ & $\mathrm{g} \mathrm{n}$ & \\
\hline 37 & rubidium & $\mathrm{Rb}$ & 85.468 & & \\
\hline 38 & strontium & $\mathrm{Sr}$ & 87.62 & $\mathrm{~g}$ & $\mathrm{r}$ \\
\hline 39 & yttrium & $\mathrm{Y}$ & 88.906 & & \\
\hline 40 & zirconium & $\mathrm{Zr}$ & $91.224(2)$ & $\mathrm{g}$ & \\
\hline 41 & niobium & $\mathrm{Nb}$ & $92.906(2)$ & & \\
\hline 42 & molybdenum & Mo & $95.96(2)$ & $\mathrm{g}$ & \\
\hline 43 & technetium* & $\mathrm{Tc}$ & & & \\
\hline 44 & ruthenium & $\mathrm{Ru}$ & $101.07(2)$ & $\mathrm{g}$ & \\
\hline 45 & rhodium & $\mathrm{Rh}$ & 102.91 & & \\
\hline 46 & palladium & $\mathrm{Pd}$ & 106.42 & $\mathrm{~g}$ & \\
\hline 47 & silver & $\mathrm{Ag}$ & 107.87 & $\mathrm{~g}$ & \\
\hline 48 & cadmium & $\mathrm{Cd}$ & 112.41 & & \\
\hline 49 & indium & In & 114.82 & & \\
\hline 50 & $\operatorname{tin}$ & $\mathrm{Sn}$ & 118.71 & & \\
\hline 51 & antimony & $\mathrm{Sb}$ & 121.76 & $\mathrm{~g}$ & \\
\hline 52 & tellurium & $\mathrm{Te}$ & $127.60(3)$ & $\mathrm{g}$ & \\
\hline 53 & iodine & I & 126.90 & & \\
\hline 54 & xenon & $\mathrm{Xe}$ & 131.29 & $\mathrm{~g} \mathrm{n}$ & \\
\hline 55 & caesium (cesium) & Cs & 132.91 & & \\
\hline 56 & barium & $\mathrm{Ba}$ & 137.33 & & \\
\hline 57 & lanthanum & $\mathrm{La}$ & 138.91 & & \\
\hline 58 & cerium & $\mathrm{Ce}$ & 140.12 & $\mathrm{~g}$ & \\
\hline 59 & praseodymium & $\operatorname{Pr}$ & 140.91 & & \\
\hline 60 & neodymium & $\mathrm{Nd}$ & 144.24 & $\mathrm{~g}$ & \\
\hline 61 & promethium* & $\mathrm{Pm}$ & & & \\
\hline 62 & samarium & $\mathrm{Sm}$ & $150.36(2)$ & $\mathrm{g}$ & \\
\hline 63 & europium & $\mathrm{Eu}$ & 151.96 & $\mathrm{~g}$ & \\
\hline 64 & gadolinium & $\mathrm{Gd}$ & $157.25(3)$ & $\mathrm{g}$ & \\
\hline 65 & terbium & $\mathrm{Tb}$ & 158.93 & & \\
\hline
\end{tabular}

(continues on next page) 
Table 5 (Continued).

\begin{tabular}{|c|c|c|c|c|}
\hline \multicolumn{5}{|c|}{ Order of atomic number } \\
\hline Atomic number & Element name & Symbol & Atomic weight & Footnotes \\
\hline 66 & dysprosium & Dy & 162.50 & $\mathrm{~g}$ \\
\hline 67 & holmium & Ho & 164.93 & \\
\hline 68 & erbium & $\mathrm{Er}$ & 167.26 & $\mathrm{~g}$ \\
\hline 69 & thulium & $\mathrm{Tm}$ & 168.93 & \\
\hline 70 & ytterbium & $\mathrm{Yb}$ & 173.05 & $\mathrm{~g}$ \\
\hline 71 & lutetium & $\mathrm{Lu}$ & 174.97 & $\mathrm{~g}$ \\
\hline 72 & hafnium & Hf & $178.49(2)$ & \\
\hline 73 & tantalum & $\mathrm{Ta}$ & 180.95 & \\
\hline 74 & tungsten & $\mathrm{W}$ & 183.84 & \\
\hline 75 & rhenium & $\operatorname{Re}$ & 186.21 & \\
\hline 76 & osmium & Os & $190.23(3)$ & $\mathrm{g}$ \\
\hline 77 & iridium & $\mathrm{Ir}$ & 192.22 & \\
\hline 78 & platinum & $\mathrm{Pt}$ & 195.08 & \\
\hline 79 & gold & $\mathrm{Au}$ & 196.97 & \\
\hline 80 & mercury & $\mathrm{Hg}$ & 200.59 & \\
\hline 81 & thallium & $\mathrm{Tl}$ & {$[204.38,204.39]$} & \\
\hline 82 & lead & $\mathrm{Pb}$ & 207.2 & $\mathrm{~g}$ \\
\hline 83 & bismuth* & $\mathrm{Bi}$ & 208.98 & \\
\hline 84 & polonium* & Po & & \\
\hline 85 & astatine* & At & & \\
\hline 86 & radon* & $\mathrm{Rn}$ & & \\
\hline 87 & francium* & $\mathrm{Fr}$ & & \\
\hline 88 & radium* & $\mathrm{Ra}$ & & \\
\hline 89 & actinium* & Ac & & \\
\hline 90 & thorium* & $\mathrm{Th}$ & 232.04 & $\mathrm{~g}$ \\
\hline 91 & protactinium* & $\mathrm{Pa}$ & 231.04 & \\
\hline 92 & uranium* & $\mathrm{U}$ & 238.03 & g m \\
\hline 93 & neptunium* & $\mathrm{Np}$ & & \\
\hline 94 & plutonium* & $\mathrm{Pu}$ & & \\
\hline 95 & americium* & $\mathrm{Am}$ & & \\
\hline 96 & curium* & $\mathrm{Cm}$ & & \\
\hline 97 & berkelium* & $\mathrm{Bk}$ & & \\
\hline 98 & californium* & $\mathrm{Cf}$ & & \\
\hline 99 & einsteinium* & Es & & \\
\hline 100 & fermium* & $\mathrm{Fm}$ & & \\
\hline 101 & mendelevium* & $\mathrm{Md}$ & & \\
\hline 102 & nobelium* & No & & \\
\hline 103 & lawrencium* & $\mathrm{Lr}$ & & \\
\hline 104 & rutherfordium* & $\mathrm{Rf}$ & & \\
\hline 105 & dubnium* & $\mathrm{Db}$ & & \\
\hline 106 & seaborgium* & $\mathrm{Sg}$ & & \\
\hline 107 & bohrium* & $\mathrm{Bh}$ & & \\
\hline 108 & hassium* & Hs & & \\
\hline 109 & meitnerium* & $\mathrm{Mt}$ & & \\
\hline 110 & darmstadtium* & Ds & & \\
\hline 111 & roentgenium* & $\mathrm{Rg}$ & & \\
\hline 112 & copernicium * & $\mathrm{Cn}$ & & \\
\hline 113 & ununtrium* & Uut & & \\
\hline
\end{tabular}


Table 5 (Continued).

\begin{tabular}{lllll}
\hline \multicolumn{4}{c}{ Order of atomic number } \\
\hline Atomic number & \multicolumn{1}{c}{ Element name } & Symbol & Atomic weight & Footnotes \\
\hline 114 & flerovium* & Fl & & \\
115 & ununpentium* & Uup & & \\
116 & livermorium* & Lv & \\
117 & ununseptium* & Uus & \\
118 & ununoctium* & Uuo & \\
\hline
\end{tabular}

*Element has no stable isotopes. One or more representative isotopes are given in Table 3 with the appropriate relative atomic mass and half-life. However, four such elements ( $\mathrm{Bi}, \mathrm{Th}, \mathrm{Pa}$, and $\mathrm{U}$ ) do have a characteristic terrestrial isotopic composition, and for these elements, standard atomic weight values are tabulated.

g Geological materials are known in which the element has an isotopic composition outside the limits for normal material. The difference between the atomic weight of the element in such materials and that given in the table may exceed the stated uncertainty.

$\mathrm{m} \quad$ Modified isotopic compositions may be found in commercially available material because it has been subjected to an undisclosed or inadvertent isotopic fractionation. Substantial deviations in atomic weight of the element from that given in the table can occur.

$\mathrm{r} \quad$ Range in isotopic composition of normal material prevents a more precise $A_{\mathrm{r}}(\mathrm{E})$ being given; the tabulated $A_{\mathrm{r}}(\mathrm{E})$ value and uncertainty should be applicable to normal material.

\section{CONVENTIONAL ATOMIC-WEIGHT VALUES FOR SELECTED ELEMENTS}

The Commission recognizes that some users of atomic-weight data only need representative values. Therefore, for those elements with standard atomic weights given as intervals, the Commission provides conventional atomic-weight values (Table 6). These conventional quantity values have no uncertainty values associated with them. They have been selected so that most or all atomic-weight variation in normal materials is covered in an interval of plus or minus one in the last digit.

Table 6 Conventional atomic weights 2011.

[For users needing an atomic-weight value for an unspecified sample, such as for trade and commerce, the following conventional values are provided.]

\begin{tabular}{llcc}
\hline Element name & Symbol & $\begin{array}{c}\text { Atomic } \\
\text { number }\end{array}$ & $\begin{array}{c}\text { Reference } \\
\text { atomic weight }\end{array}$ \\
\hline boron & $\mathrm{B}$ & 5 & 10.81 \\
bromine & $\mathrm{Br}$ & 35 & 79.904 \\
carbon & $\mathrm{C}$ & 6 & 12.011 \\
chlorine & $\mathrm{Cl}$ & 17 & 35.45 \\
hydrogen & $\mathrm{H}$ & 1 & 1.008 \\
lithium & $\mathrm{Li}$ & 3 & 6.94 \\
magnesium & $\mathrm{Mg}$ & 12 & 24.305 \\
nitrogen & $\mathrm{N}$ & 7 & 14.007 \\
oxygen & $\mathrm{O}$ & 8 & 15.999 \\
silicon & $\mathrm{Si}$ & 14 & 28.085 \\
sulfur & $\mathrm{S}$ & 16 & 32.06 \\
thallium & $\mathrm{Tl}$ & 81 & 204.38 \\
\hline
\end{tabular}




\section{PERIODIC TABLE OF THE ISOTOPES}

The Periodic Table of the Elements, developed independently by Mendeleev and Meyer in the late $19^{\text {th }}$ century, represents a remarkable achievement in our understanding of the structure of the atoms and the chemical and physical properties of the elements. Traditionally, the Periodic Table includes the standard atomic weights of the elements. With the introduction of intervals to represent the standard atomic weights for elements that have large variations in isotopic abundance from which atomic weights are calculated, members of the Commission together with assistance from the IUPAC Committee on Chemistry Education proposed to develop a periodic table of the isotopes for the educational community [45]. The goal of this IUPAC-sponsored project is to produce learner-oriented materials on an interactive periodic table to emphasize the existence of isotopes, the role of isotopic abundances in the determination of atomic weights, and applications in science and industry.

The IUPAC Periodic Table of the Isotopes produced by members of the task group, shown in Fig. 4, employs colored tiles to distinguish among four categories of the elements: (a) element with two or more isotopes that are used to determine the standard atomic weight, which varies in normal materials and is represented with an interval; (b) element with two or more isotopes with variable isotopic abundances that are used to determine the standard atomic weight, but the upper and lower bounds of the standard atomic weight have not been assigned by IUPAC or the variations may be too small to affect the atomic-weight value; (c) element with only one isotope that is used to determine the standard atomic weight; and (d) element with no standard atomic weight because all of its isotopes are radioactive and no isotope occurs with a characteristic terrestrial isotopic composition in normal materials.

\section{IUPAC Periodic Table of the Isotopes}

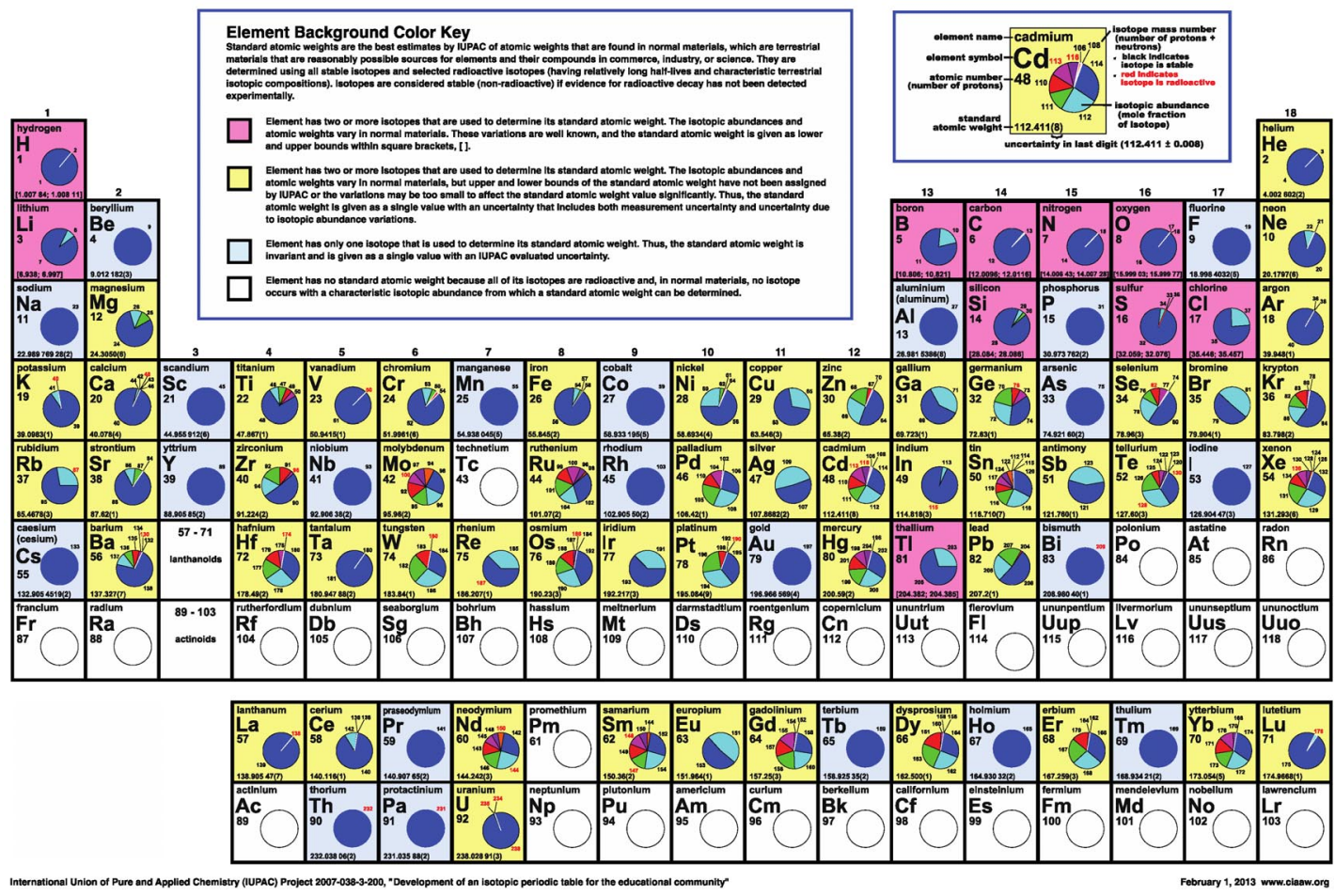

Fig. 4 IUPAC Periodic Table of the Isotopes. This is a revised and updated version [46] of the figure originally presented in ref. [47]. 
In addition, pie diagrams provide an overview of the relative abundances of the isotopes that were used in the determination of standard-atomic-weight values.

\section{MEMBERSHIP OF SPONSORING BODIES}

Membership of the Inorganic Chemistry Division Committee for the period 2010-2011 was as follows:

President: R. D. Loss (Australia); Past President: K. Tatsumi (Japan); Secretary: L. V. Interrante (USA); Vice President: J. Reedijk (Netherlands); Titular Members: T. Ding (China); N. E. Holden (USA); P. Karen (Norway); J. Garcia-Martinez (Spain); S. Mathur (Germany); K. Sakai (Japan); Associate Members: T. V. Basova (Russia); M. Drábik (Slovakia); M. Leskela (Finland); L. K. Liu (China/Taipei); L. R. Öhrström (Sweden); T. B. Coplen (USA); National Representatives: T. Hossain Tarafder (Bangladesh); N. Trendafilova (Bulgaria); Chandrasekhar (India); R. Gonfiantini (Italy); T. Dasgupta (Jamaica); K. Yoon (Korea); L. Y. Goh (Malaysia); A. Kilic (Turkey); A. West (UK); A. Bologna Alles (Uruguay).

Membership of the Commission on Isotopic Abundances and Atomic Weights for the period 2010-2011 was as follows:

Chair: W. A. Brand (Germany); Secretary: M. Wieser (Canada); Titular Members: M. Berglund (Belgium); M. Gröning (Austria); T. Hirata (Japan); R. Schoenberg (Germany); T. Walczyk (Singapore); S. Yoneda (Japan); Associate Members: J. Meija (Canada); T. Prohaska (Austria); T. Walczyk (Singapore); X. K. Zhu (China); P. Vallelonga (Australia); National Representatives: J. K. Böhlke (USA); P. De Bièvre (Belgium); S. Yoneda (Japan).

The Commission on Isotopic Abundances and Atomic Weights notes the death of a former member and secretary of the Commission. Prof. J. R. de Laeter, 1933-2010, was an expert in both radioactive and stable isotopes, and the measurement and evaluation of atomic weights. A long-time active contributor to IUPAC, John held various positions as an Associate Member, Titular Member, National Representative, Secretary of the Commission, and Chair of the Commission, and other subcommittees over the period 1980-2010. One of John's significant achievements was leading a major overview of the atomic weights of the elements during the $20^{\text {th }}$ century, published in $2003[10,11]$.

\section{ACKNOWLEDGMENTS}

The support of the U.S. Geological Survey National Research Program made this report possible. The following IUPAC projects contributed to this Technical Report: 2007-029-1-200, 2007-028-1-200, 2007-038-3-200, 2009-025-2-200, and 2009-029-1-200.

\section{REFERENCES}

1. N. E. Holden. Chem. Int. 26, 4 (2004).

2. IUPAC. Pure Appl. Chem. 18, 569 (1969).

3. P. De Bièvre. Z. Anal. Chem. 264, 365 (1973).

4. H. S. Peiser, N. E. Holden, P. De Bièvre, I. L. Barnes, R. Hagemann, J. R. de Laeter, T. J. Murphy, E. Roth, M. Shima, H. G. Thode. Pure Appl. Chem. 56, 695 (1984).

5. H. S. Peiser, N. E. Holden, P. De Bièvre, I. L. Barnes, R. Hagemann, J. R. de Laeter, T. J. Murphy, E. Roth, M. Shima, H. G. Thode. Errata, Pure Appl. Chem. 79, 951 (2007).

6. M. E. Wieser. Pure Appl. Chem. 81, 2131 (2009).

7. BIPM. Guide for Expression of Uncertainty in Measurement (GUM), Bureau International des Poids et Mesures, Geneva (2008); www.bipm.org/en/publications/guides/gum.html

8. M. Berglund, M. E. Wieser. Pure Appl. Chem. 83, 397 (2011).

9. M. E. Wieser, T. B. Coplen. Pure Appl. Chem. 83, 359 (2011). 
10. J. R. de Laeter, J. K. Böhlke, P. De Bièvre, H. Hidaka, H. S. Peiser, K. J. R. Rosman, P. D. P. Taylor. Pure Appl. Chem. 75, 683 (2003).

11. J. R. de Laeter, J. K. Böhlke, P. De Bièvre, H. Hidaka, H. S. Peiser, K. J. R. Rosman, P. D. P. Taylor. Errata, Pure Appl. Chem. 81, 1535 (2009).

12. N. E. Holden, R. L. Martin. Pure Appl. Chem. 55, 1101 (1983).

13. G. Audi, A. H. Wapstra, C. Thibault. Nucl. Phys. A 729, 337 (2003).

14. IUPAC, Commission on Isotopic Abundances and Atomic Weights (CIAAW). http://www.ciaaw.org/atomic_weights9.htm.

15. IUPAC Inorganic Chemistry Division. Evaluation of radiogenic abundance variations in selected elements (IUPAC Project \#2009-023-1-200, http://www.iupac.org/project/2009-023-1-200) (accessed 5 March 2013).

16. T. B. Coplen, J. K. Böhlke, P. De Bièvre, T. Ding, N. E. Holden, J. A. Hopple, H. R. Krouse, A. Lamberty, H. S. Peiser, K. M. Révész, S. E. Rieder, K. J. R. Rosman, E. Roth, P. D. P. Taylor, R. D. Vocke Jr., Y. K. Xiao. Pure Appl. Chem. 74, 1987 (2002).

17. T. B. Coplen, J. A. Hopple, J. K. Böhlke, H. S. Peiser, S. E. Rieder, H. R. Krouse, K. J. R. Rosman, T. Ding, R. D. Vocke Jr., K. M. Révész, A. Lamberty, P. Taylor, P. De Bièvre. Compilation of Minimum and Maximum Isotope Ratios of Selected Elements in Naturally Occurring Terrestrial Materials and Reagents, U.S. Geological Survey, Water-Resources Investigations Report (WRI) 01-4222 (2002).

18. T.-L. Chang, W.-J. Li. Chin. Sci. Bull. 35, 290 (1990).

19. BIPM. International Vocabulary of Metrology - Basic and General Concepts and Associated Terms (VIM), $3^{\text {rd }}$ ed., Bureau International des Poids et Mesures, Geneva (2008 version with corrections); JCGM 200:2012 at http://www.bipm.org/en/publications/guides/vim

20. T. B. Coplen. Rapid Commun. Mass Spectrom. 25, 2538 (2011).

21. M. Elvert, E. Suess, J. Greinert, M. J. Whiticar. Org. Geochem. 31, 1175 (2000).

22. T. B. Coplen, H. S. Peiser. Pure Appl. Chem. 70, 237 (1998).

23. (a) F. W. Clarke. J. Am. Chem. Soc. 16, 179 (1894); (b) F. W. Clarke. J. Am. Chem. Soc. 17, 201 (1895); (c) F. W. Clarke. J. Am. Chem. Soc. 18, 197 (1896); (d) F. W. Clarke. J. Am. Chem. Soc. 19, 359 (1897); (e) F. W. Clarke. J. Am. Chem. Soc. 20, 163 (1898); (f) F. W. Clarke. J. Am. Chem. Soc. 21, 200 (1899); (g) F. W. Clarke. J. Am. Chem. Soc. 22, 70 (1900).

24. IUPAC. Nomenclature of Inorganic Chemistry, IUPAC Recommendations 2005 (the "Red Book"). Prepared for publication by N. Connelly, T. Damhus, R. M. Harshorn, RSC Publishing, Cambridge, UK (2005).

25. E. J. Catanzaro, T. J. Murphy, E. L. Garner, W. R. Shields. J. Res. Natl. Bur. Stand. (U.S.) 68A, 593 (1964).

26. O. Shouakar-Stash, S. K. Frape, R. J. Drimmie. Anal. Chem 77, 4027 (2005).

27. O. Shouakar-Stash, S. V. Alexeev, S. K. Frape, L. P. Alexeeva, R. J. Drimmie. Appl. Geochem. 22, 589 (2007).

28. D. Carrizo, M. Unger, H. Holmstrand, P. Andersson, O. Gustafsson, S. P. Sylva, C. M. Reddy. Environ. Chem. 8, 127 (2011).

29. L. Yang, J. Meija. Anal. Chem. 82, 4188 (2010).

30. L. Yang, R. E. Sturgeon, Z. Mester, J. Meija. Anal. Chem. 82, 8978 (2010).

31. M. Bizzarro, C. Paton, K. Larsen, M. Schiller, A. Trinquier, D. Ulfbeck. J. Anal. At. Spectrom. 26, 565 (2011).

32. F. Wombacher, A. Eisenhauer, F. Böhm, N. Gussone, M. Regenberg, W.-Chr. Dullo, A. Rüggeberg. Geochim. Cosmochim. Acta 75, 5797 (2011).

33. N. J. Pearson, W. L. Griffin, O. Alard, S. Y. O’Reilly. Chem. Geol. 226, 115 (2006).

34. U. Wiechert, A. N. Halliday. Earth Planet. Sci. Lett. 256, 360 (2007).

35. A. Galy, N. S. Belshaw, L. Halicz, K. O’Nions. Int. J. Mass Spectrom. 208, 89 (2001).

36. E. T. Tipper, A. Galy, M. J. Bickle. Earth Planet. Sci. Lett. 247, 267 (2006). 
37. E. B. Bolou-Bi, N. Vigier, A. Brenot, A. Poszwa. Geostand. Geoanal. Res. 33, 95 (2009).

38. E. B. Bolou-Bi, N. Vigier, A. Poszwa, J. Boudot, E. Dambrine. Geochim. Cosmochim. Acta 87, 341 (2012).

39. E. J. Catanzaro, T. J. Murphy, E. L. Garner, W. R. Shields. J. Res. Natl. Bur. Stand. (U.S.) 70A, 453 (1966).

40. E. J. Catanzaro, T. J. Murphy. J. Geophys. Res. 71, 1271 (1966).

41. J. Meija, L. Yang, R. E. Sturgeon, Z. Mester. J. Anal. At. Spectrom. 25, 384 (2010).

42. M. G. Zadnik, S. Specht, F. Begemann. Int. J. Mass Spectrom. Ion Processes 89, 103 (1989).

43. M. Wang, G. Audi, A. H. Wapstra, F. G. Kondev, M. MacCormick, X. Xu, B. Pfeiffer. Chin. Phys. C 36, 1603 (2012).

44. N. E. Holden. "Table of the isotopes (revised 2010)", in Handbook of Chemistry and Physics, $93^{\text {rd }}$ ed., W. M. Haynes (Ed.), Section 11, pp. 2-174, CRC Press, Boca Raton (2012) and updates.

45. IUPAC Inorganic Chemistry Division. Development of an isotopic periodic table for the educational community. IUPAC project \#2007-038-200, http://www.iupac.org/project/2007-038-200 (accessed 5 March 2013).

46. IUPAC, Commission on Isotopic Abundances and Atomic Weights (CIAAW). http://www.ciaaw.org/pubs/Periodic_Table_Isotopes.pdf (accessed 5 March 2013).

47. IUPAC. The Periodic Table of the Isotopes: First Release. Chem. Int. 33, 20 (2011). http://www.iupac.org/publications/ci/2011/3304/pp6_2007-038-3-200.html (accessed 5 March 2013).

Republication or reproduction of this report or its storage and/or dissemination by electronic means is permitted without the need for formal IUPAC permission on condition that an acknowledgment, with full reference to the source, along with use of the copyright symbol $\odot$, the name IUPAC, and the year of publication, are prominently visible. Publication of a translation into another language is subject to the additional condition of prior approval from the relevant IUPAC National Adhering Organization. 